University of Louisville

ThinkIR: The University of Louisville's Institutional Repository

Electronic Theses and Dissertations

3-1947

\title{
A correlation of plate efficiencies in fractionating columns.
}

Earl K. Stigger 1920-2007

University of Louisville

Follow this and additional works at: https://ir.library.louisville.edu/etd

Part of the Chemical Engineering Commons

\section{Recommended Citation}

Stigger, Earl K. 1920-2007, "A correlation of plate efficiencies in fractionating columns." (1947). Electronic Theses and Dissertations. Paper 2173.

https://doi.org/10.18297/etd/2173

This Master's Thesis is brought to you for free and open access by ThinkIR: The University of Louisville's Institutional Repository. It has been accepted for inclusion in Electronic Theses and Dissertations by an authorized administrator of ThinkIR: The University of Louisville's Institutional Repository. This title appears here courtesy of the author, who has retained all other copyrights. For more information, please contact thinkir@louisville.edu. 


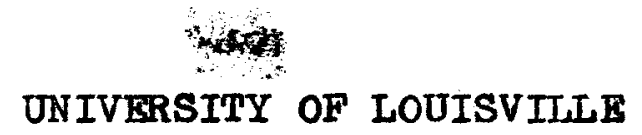
A CORRELATION OF PLATE FFFICIENCIES IN FRACTIONATING COLUMNS

\author{
A Thes 10 \\ Submitted to the Faculty \\ of the Graduate School \\ of the University of Louisville \\ in Partial Fulfiliment \\ of the Requirement. \\ for the Degree of \\ MASTER OF CHEMICAL ENGINEERING \\ Department of Chemical Enginooring
}

Earl K. St Iggor

Yarch 1947 


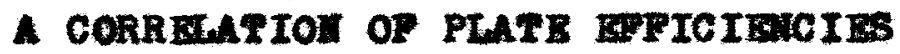

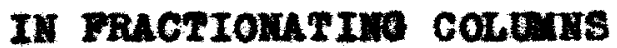

Dar1 x. 8tigsor

Apprered by the Eranining Comitteo

Directer $\quad$ G. C. Williams

R. C. Ernst

Guy Stevenson

Marah 1847 
TABLE OF CONTEMTS

Page

Llat of Tables ................ IV List of Plgures .................. v Abstract ..................... v1 Acknew ledgrent .................. v11 Intreduct 1on . . . . . . . . . . . . 1 Hiaterleal ................... 4 Thoorotical ................. 12 Exporimental . . . . . . . . . . . . . 22 Equipment ................. 23 Syst ems Inveutigat od . . . . . . . . . 24 Operat Ing Procedure . . . . . . . . . 27 Data and Results .............. 30 Disouscion of Results .............. 50 Summary and Conclusions . . . . . . . . . 59 Litorature clted . . . . . . . . . . . 62 Append1x . . . . . . . . . . . . . . . 64 plan of Colum .............. 65 Dota1la of Plat Construotion ....... 66 Samplo Calculations ............ 67 Hemenolature ................ 71 Acknonled gment . . . . . . . . . . . . 73 vita .......................74 


\section{IIST OP TABLES}

Table Ne.

Pago

I Vapor-Liquid guilibria for Ethane1-Nator

II Vapor-Liquid Equilibria for Methanol-mater 28

III Vaper-Liquid pullibria fer Bensene-teluene

IV Vapor-Liquid Equlibria for Carbon

Tetrachlerlde-Benzene

V Vapor-Liquid Aulilbria for Acotaldohyde-Fator

VI Results for Etbanol-nat or Fractionatiene

VII Resulte for Methanel-Wat or Practionations

VIII Results for Benzene-Feluene Frationatione

IX Fesults for Carbon Tetrechloride-Benzene

Fraet Lonat 1one

X Reault for Leetaldohyde-Water Fractiontiona

XI Average Revults by Bjoteno 48

XII Dovlation of Reanlte for Rotal Rerlux Operation 52

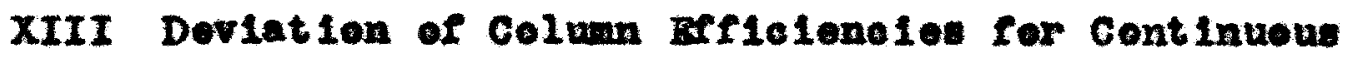
Operation

XIV Deviation of Reotifier Efiolenciea for

Continuous oporatien

XV Deviation of Stripper Effleteneles for

Continuous operation

XVI Deriation of the Average Resulta fron the 
LIST OP PIOURES

Plgure ne.

Page

1 Bfrect of Viscesity on Plate Bficiency

2 Refeot of Relative Volatility and Viseonity on Plate Eficionoy

3 Typloal Data shoet for Ethanel-Water 32

4 Typical Data sheot for Methanol-Water 33

5 Typioal Data sheet for Benzene-Toluene 34

6 Typleal Data sheet for Carben Tetrachloride-ienzene 35

7 Typlesi Data Sheot for Acetaldehyde-Water 36

8 Effoet of Relative Volatility and Viecesty on Plate Bfflelency - Totil Reflux operation

- Erfeot of Relative Velatility and Viseosity on plate zerielencs - Continuoue operation

10 Frfect of Relative Volatilits and Viscenity on Plate Brflelenoy - - Continuous Reotifier

11 Effect of Relative Velatility and Viscesity on Plate Brficleney - - Continuous Stripper

12 grfect of Relative Velatility and viacesity on Plate Eficloney - Average Reaulta

13 Erfect of Rerlux Ratio on Ovorall Efriclency in Motbanel-Hat or Rootification

14 Bxperimental Fractionating Celuma 65

15 Detalla of Plate conotruotien 68

16 Sample calculation of Theoretical Plate 60 
ABSTRACT

A varioty of binary aystems nore used in obtaining fractionation data in the same rectification colum. The column was large onough to permit the nes of a correlation for predicting plate officione1es in commeralal fractionatiors, and yielded results well within the limita of mechanioal des1gn. Eatablished correlat lons were shown adequately to represent the results over wide variation in both relative velatility and viscosity. 


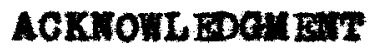

The author wiahod to ackmonledge

the kind asiatance and holpful guldance or Dr. O. C. T1211ame.

whe alreet ed this research 
IXmRCDUCrion 
In the design of commercial fract lonat ing column, one of the major itens is the number of plates or trays to be used in order to preduce a givon separation. Numerous Inveatigators $(1,2,3,4)$ have present ed viglous methods by which the required number of theoretical plates may be calculated. The thearetical plate concopt assumes that equilibriwa is attalned between the liquid and vapor phases; but since, in practioe, equilibrium is soldon, if over, roached, this theoretical treatment jlelds results which may be as low as twenty percent of the actual number of plates required. The varlance botween the actual and tho theoretical number of plates has been grouped in a coefflolont called plate offlofonoy, and attribut ed to rerious meohanical oharacteriatios of the equipment and the water1als undergolng seperation.

The mechanical features and their of fect have been discussed in numerous art10les $(5,6,7,8,9,10)$. The firat eignificant treatment of the effect of the phyoles properties of the materials being eeparated was presented by Walter and Shorwood (11) who Indicated that the officlonoy of tower absorbers was a function of the v1seosity. Later workers $(12,13)$ showed that viscesity also affected the plate effloloney of fractionating celums. O'Connell (14) expand ed the werk or other investigat ore to shon a corrolation of plate effielenoy in fractionators a a 
function of viscosity and the relative volatility of the key components. Systoms of matorlals which seemed to disagreo with correlation of plate officiency a function of viscosity alone were brought into oloser agreement when correlated on the basis of viscosity and the relative volatility of the koy components. The work of o'Connell was based on data published by other Investigat ors using alferent columns.

The purpose of the material presented in this paper is to evaluat and expand the correlation of plate efflelency as function of viscosity and relative volat 1lity. The data presented for all these systoms were obtalned on the same celumn, and the systems were chosen to cover definite ranges of the physical properties. Duplication of syst on types was avolded, whoro possible, in order to broden the scope of the final correlation. 
mISTORICAL 
Although the practice of fractionation wae doveloped centuriee age, for many yeare there was no real enginearing deaign of equipment. The first worthwhile attempt to rational120 column design was present od by Sorel (4) at the end of the ninoteenth oent ury. Sorel worked from equilibrium rolationships between 11quid and vaper alxtures. If it wore possible to obtain vapor-11quid equilibriun, Sorel would have selved the question of column design from the standpolnt of the number of plates roquired for given soparation. In pract loally overy case, howovor, the attaimment of equilibrium is impossible, and field was oponod for investigators to find a dofinite basis for the difference between the thooret 1eal and the actual number of neoesangy plates.

The diserepaney botween sotuel and theoret leal plates, termed offlolency, required mathematioal description. This expression took three general forms: (1) point offieioney, (2) Murphree plate offleloney, and (3) orerall offlolenog.

Point offieloncy 1s described as the offleloney at one point on any plate in a colvan, and is the ratio of the enrichment obtained to the onrichment und or equilibrium conditions at the designat od point.

Murphree plate effieleney is os sentially the same as point offloloney oxeopt that the onxlohment 18 based on the average composition of vapor ont oring and leaving a plate, 
and the liquid leaving the plate.

overall efflelenoy is the ratio of the thooretieal number of plates to the ectual number of plates roquired for a Eiven separation.

For englneering calculations, overall officlency values are the nost consiatent and in most cases the least difficult to obtain.

Barly workers, not ing that different columns gave different operating charactoristics for sinilar materials, made an effort to relate the colum efficiency to mechanical design aspects of the column.

Peavy and Baker (5) Inveat igated the effect of vapor velocity on plate effieleney, and reported that plate efflelency increases with increasing veloeity, becoming fairly constant over a considerable range at noderate velocities. At high velocities, effielency falls off as a result of entrainment and liquid carry-over to the next plate. In order to determine the optimun velocity on the basis of maximum effleleney, a method was developed by Brown and souders (6) and oxpanded by Brown and Lockhart (7). Carey ot al (8) determined the effect of slot submergence and slot velocity on plate efflelency. They concluded that the effictency Increased as lot submergence Increased; and, for normal operating velocities, the efflolency was essentlally independent of slot veloelty. 
rirkbride (9) present od method for calculating the downcomer area required to prevent celumn flooding and the deleterious effoet of floeding on stable celumn operation is well known.

In order to Insure stable plate operation, the liquid load must be malntained belon the value which would produce greater 11quid head at the ontrance to the plate than at the overflon from the plate. Allowable liquid loads are prediotable according to the method discussed by Oood ot al (10).

O'Connell (24) has stated: "The dlameter of the colum does not affect plate offlelenoy for diameters less than five feet. However, for colume larger than seven feet, the length of the liquid path (Cross flow offect) muat be taken into account."

The effect of mochanical dosign fectors on plate offleleney has been confirmed in practice. Yot, when a column 1a designed for optimum officienoy, based on these mechanical factors, a wide range of efflelencies my be obtelned when the column 18 operated with different systeme. This variation euggested the possibility that physical properties of the process materials might affect the orficieney of the eparation. One of the first physical properties investigat od with rogard to it effect on plate officieney was viscosity. 
Falter and shorwood (11) had shown that in the absorption of various materials the absorption effioloney Inereased with decreasing viscosity of the absorbant, while Keyes and Byman (12) showed evidence of viscolty affecting plate effleionoy in laboratory distillations of ethanolrater migtures.

If viscosity affects absorption effloioney, as has boen shown by walt ar and Shorwood, then it follow that there should be almilar offeet in frectionation, since both operations involve diffusional processed. This conelusion 1a basod on the postulation that the major portion of the onrlchment during eractionation is a result of selective counter-diffusion of the key components in the freth above the plate.

Host of the work on riscosity involved the use of laboratory data and was theroby limited as to comercial application. Driokamer and Bracerd (13) prosented derinite correletion of plate efficieney as a function of viscosity (Plgure I) wherein the effleleney whs shown to inorease with deoreasing viacosity. Although the date were obtalned from somereial oporations, the use of the relation is limit ed to systens of hydrocarbong having low relative volitility between the key componente. Gerstor, Koffelt, and Withron (15) Indieated that the actual number of pletes required for a given eparation 


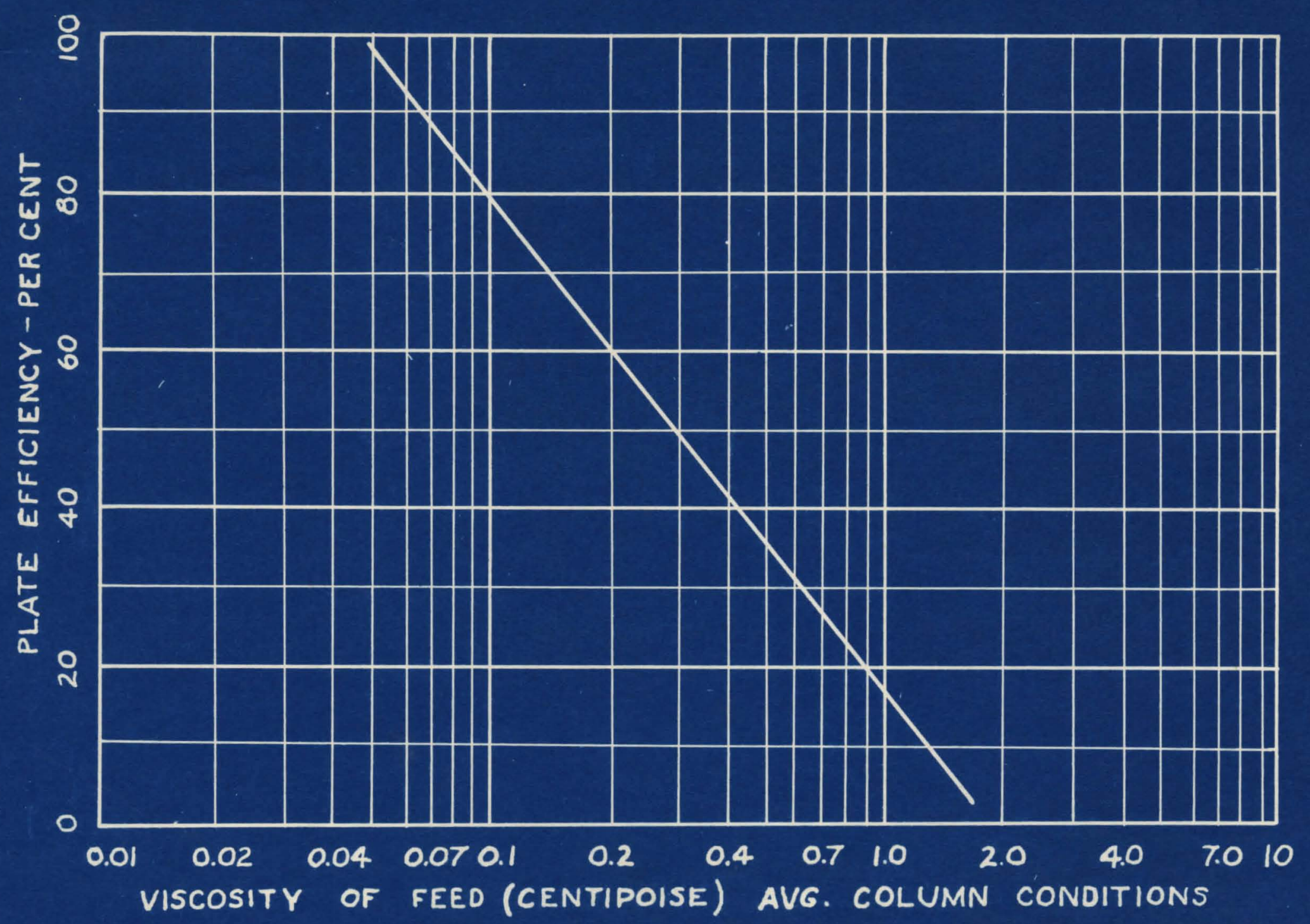

FIG. I - EFFECT OF VISCOSITY ON PLATE EFFICIENCY (CORRELATION OF DRICKAMER AND BRADFORD) 
was function of the slope of the equilibrium curve. From this, O'Connell (24) dodued that the limitations of the correlation of Drlokamer and Bradford could be reduced by correlating plate effloleney as affected by viscosity and tive relative velatility of the key components. The oorrelation (Figure 2) incorporated data for several nonhydrocarbon ayetens, and for aystoms of relatively high volatilities. Although the correlation was not specific, It was considered well within the limits of fractionation calculations in general and botter commercial adaptation resulted. The correlstion was not fitted with equations. 


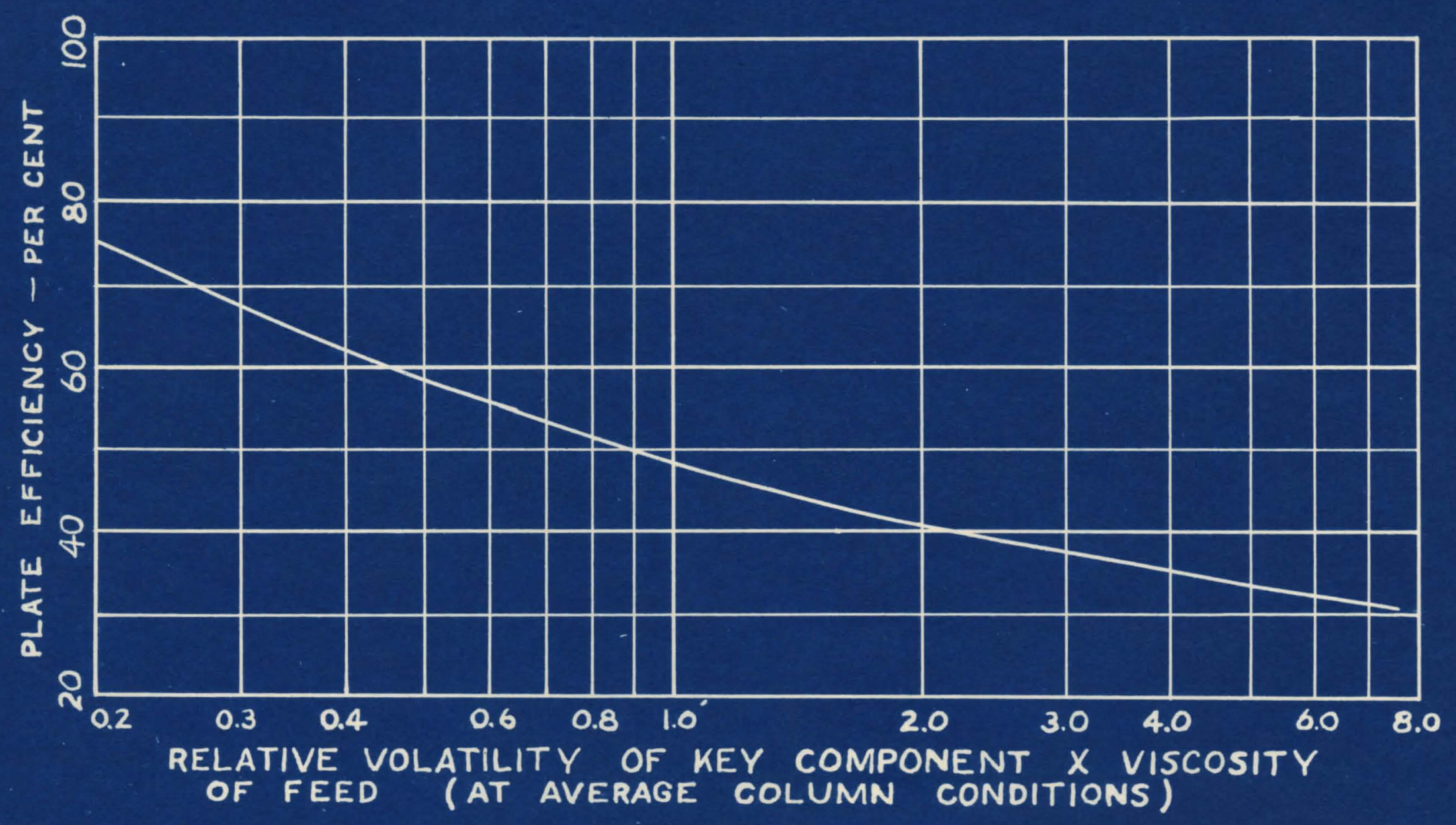

FIG. 2 - EFFECT OF RELATIVE VOLATILITY AND VISCOSITY ON PLATE EFFICIENCY

(CORRELATION OF O'CONNELL) 
THEOREPTCAL 
A. Ffeet of Viscoalty on Plate Efflelenoy

The theoret leal background for the offect of viscosity on plate offleloney was sumarized by Drickamer and Bradford (13).

First, the stokes-Einst ein equation for diffusivity,

$$
k=\frac{R T}{6 \pi k r}
$$

prosents diffusivity, $k$, as inverse function of viscesity, $z$.

The equation for ass transfor developed by Chilton and Colburn (16) Indicates that wass transfor und or turbulent conditions, $x, 18$ an inverse function of viscesity, $z$.

$$
\mathbf{x}=\frac{01}{\mathbf{L}}\left(\frac{\rho_{k}}{2}\right)^{0.67}
$$

Further evidence of note is the von Karmen (17) equation for film thickness:

$$
=\frac{\text { (oonstant) (Z) }}{a\left(\frac{1}{2}\right)}
$$

whore the film thickness, $s$, is shown to be a direct function of the viscosity, $z$.

Sherwoed and walter (11) developed an equation for liquid mass transfor,

$$
\mathrm{I}=\frac{3.4}{0.58}
$$

which ind loated an inverse relationship between the 11quid 
mass transfor coofflolent, $K$ and viscosity, $Z$.

Although none of those equations ind loates a definite mathemalioal relationahip between viscosity and plate offlelency, thoy all show that viscosity ont ors into the value of numerous factors which do affect the degree of soparation attalnablo through tractionation.

B. Ef fect of Relative Volatility on Plate Efflolency In the work of Cerster, Koffolt, and witbrow (5) 1t was point ed out that the slope of the equilibrium ourve had a drect bearing on the actual number of plates required per transfor unit. If the number of transfor units is equal to, or has alrect relation to, the number of theoretical plates required, then the plate offletenoy may also be considered function of the slope of the equilibrium curve. If the relative volatility is a funetion of the slope of the equilibrium curve, or, more precisely, mathematicel representation of the slope, then it follows that there should be connection between plate offlolency and relative volat 111ty.

Although no theoretical explanation for the relationship is available, $0^{\prime C o n n e l l ~(14) ~ p r e s e n t s ~ t h e ~}$ following in support of such o conclusion.

The effoct of the relative velatility was shown by the results of a test on an ethylene dichlorlde stabilizor. In this column, the roed contalned 
both wat or and ethyl chloride whioh had to be redued to low concentrations in the ethulene dichlorlde bottoms. The plate offlelency based on water as the lon boliling key componont (ethylone dichlorlde the high bolling key) was 294 and the relative volatility botween water and othylene dichloride was 16. The plate offloleney based on othyl chloride as the low bolling key compenent was 57\%, and the relative volatility between othyl chloride and ethylene dichloride was $3.1 . "$

The presentation of plate efflolency as function of the product of the riscosity and the relative volatility has little theoretical background. A correlation reaulted, however, which Indleated that the offloleney Inereased as the viscosity-volatility produet decreased. (See Figure 2, Page 11.)

c. Theoretical Plate Caleulations and Builibrium Data The theoretieal number of plates corresponding te a givon soperation may bo celoulat d by any of numerous methods reperted in the literature. For the purpose of the correlation in question, it was considered that the graphical Mocabo-Thiole method would suffioe. This selection wa besed on simplieity and general acceptance. For binary systems, the Mecabe-Thiele methed is simple, and the results are vithin the normal 2imits of engineering calculations.

Vapor-11quid oquilibrium data nere caleulated by the methed of Chilton and Colburn (16). In the oquilibrium 
data, Tables I, II, III, IV, and V,

$x_{h}$ is the mol fraction of the more volatile oompenent in the 1iquid

$y_{A}$ is the mol fraction of the more velatile component in the vapor

$t_{b}$ is the bolling temperature, degrees cent igrade

$\alpha$ is the relative volatility, $\frac{\frac{y}{I-y^{\prime}}}{\frac{x^{\prime}}{1-x h}}$

D. Viscosity Date

V1scesity values wer obtained from standard references and the values used in the corrolation are the 'psuedo molal viscesities' of Drickamer and Bradford (13). The psuede viscosity assumes that viscosities of mixtires may be determined by adding the viscesitios of the component at the given temperature in proportion to the mol fraction of each prosent:

$$
\begin{aligned}
& \mu=x A \mu A+x B \mu B \\
& \text { where, } \mu \text { is the viscosity in centipoise } \\
& \text { A denotes component } \\
& \text { B denotes component } \\
& \times 18 \text { mol fraction }
\end{aligned}
$$


Tablo I: Vapor-LIquid Bquilibria for Ethanol-Water

\begin{tabular}{|c|c|c|c|}
\hline$x_{A}$ & $\mathbf{y}_{\mathbf{A}}$ & $t_{b}$ & $\alpha$ \\
\hline 0.00 & 0.000 & 100.0 & $-\cdots$ \\
\hline 0.005 & 0.052 & 98.6 & 10.9 \\
\hline 0.010 & 0.100 & 97.3 & 11.0 \\
\hline 0.015 & 0.145 & 96.1 & 11.0 \\
\hline 0.020 & 0.188 & 95.0 & 10.9 \\
\hline 0.030 & 0.250 & 93.2 & 10.8 \\
\hline 0.06 & 0.337 & 90.4 & 9.65 \\
\hline 0.07 & 0.389 & 88.5 & 8.45 \\
\hline 0.10 & 0.443 & 86.4 & 7.15 \\
\hline 0.15 & 0.497 & 84.4 & 5.60 \\
\hline 0.20 & 0.530 & 83.2 & 4.50 \\
\hline 0.30 & 0.574 & 81.7 & 3.14 \\
\hline 0.40 & 0.613 & 80.7 & 2.37 \\
\hline 0.50 & 0.653 & 80.0 & 1.880 \\
\hline 0.60 & 0.699 & 79.4 & 1.548 \\
\hline 0.70 & 0.752 & 78.9 & 1.300 \\
\hline 0.80 & 0.817 & 78.4 & 1.117 \\
\hline 0.95 & 0.846 & 78.2 & 0.940 \\
\hline 1.00 & 1.000 & 78.3 & $\ldots$ \\
\hline
\end{tabular}

Calculated at 760 motal pressure by the mothod of Chilton and Colburn (26) 
Table II: Vepor-liquid Buflibria for Methanol-Wat or

\begin{tabular}{|c|c|c|c|}
\hline$x_{A}$ & $\mathbf{y}_{\mathbf{A}}$ & $t_{b}$ & $\alpha$ \\
\hline 0.00 & 0.000 & 100.0 & $\cdots$ \\
\hline 0.05 & 0.277 & 92.6 & 7.27 \\
\hline 0.10 & 0.420 & 87.7 & 6.52 \\
\hline 0.20 & 0.576 & 82.0 & 5.45 \\
\hline 0.30 & 0.665 & 78.5 & 4.64 \\
\hline 0.40 & 0.729 & 75.8 & 4.04 \\
\hline 0.50 & 0.781 & 73.7 & 3.57 \\
\hline 0.60 & 0.831 & 72.6 & 3.29 \\
\hline 0.70 & 0.876 & 69.7 & 3.02 \\
\hline 0.80 & 0.918 & 68.0 & 2.79 \\
\hline 0.90 & 0.959 & 66.4 & 2.57 \\
\hline 0.95 & 0.970 & 65.6 & 2.50 \\
\hline 1.00 & 1.000 & 64.6 & $\ldots$ \\
\hline
\end{tabular}


Table III: Vaper-Llquid Bqullibria for Benzene-Tolueno

$\begin{array}{cccc}x_{\mathrm{A}} & \mathrm{y}_{\mathrm{A}} & \mathbf{t}_{\mathrm{b}} & \alpha \\ 0.00 & 0.000 & 110.7 & 2.315 \\ 0.05 & 0.113 & 108.5 & 2.330 \\ 0.10 & 0.207 & 106.3 & 2.345 \\ 0.20 & 0.375 & 102.2 & 2.374 \\ 0.30 & 0.507 & 98.6 & 2.404 \\ 0.40 & 0.618 & 85.5 & 2.433 \\ 0.60 & 0.712 & 82.5 & 2.463 \\ 0.60 & 0.790 & 89.8 & 2.492 \\ 0.70 & 0.855 & 87.2 & 2.522 \\ 0.80 & 0.912 & 84.6 & 2.551 \\ 0.90 & 0.959 & 82.3 & 2.581 \\ 0.95 & 0.981 & 81.2 & 2.595 \\ 1.00 & 1.000 & 80.1 & 2.610\end{array}$

Calculated at $760 \mathrm{~mm}$ total pressure by the nothed of Chilton and colburn (16) 
Table IV: Vapor-Liquid Rullibria for Carben Tetrachloride-Benzene

$\begin{array}{llll}\boldsymbol{x}_{\mathrm{A}} & \bar{J}_{\mathrm{A}} & t_{\mathrm{b}} & \alpha \\ 0.00 & 0.000 & 80.2 & 1.260 \\ 0.05 & 0.0615 & 79.8 & 1.245 \\ 0.10 & 0.120 & 79.4 & 1.229 \\ 0.20 & 0.230 & 78.7 & 1.295 \\ 0.30 & 0.333 & 78.1 & 1.264 \\ 0.40 & 0.432 & 77.7 & 1.139 \\ 0.50 & 0.526 & 77.3 & 1.113 \\ 0.60 & 0.620 & 77.0 & 1.090 \\ 0.70 & 0.714 & 76.7 & 1.068 \\ 0.80 & 0.806 & 76.6 & 1.043 \\ 0.90 & 0.902 & 76.5 & 1.025 \\ 0.95 & 0.951 & 76.4 & 1.015 \\ 1.00 & 1.000 & 76.4 & 1.007\end{array}$

Caloulated at $760 \mathrm{~mm}$ totel preasure by the mothod of Chilt on and Colburn (26) 
Table V: Vapor-liquid Equilibria for Aeotaldohyde-water

$\begin{array}{lccc}x_{A} & y_{A} & t_{b} & \alpha \\ 0.00 & 0.000 & 100.0 & 54.6 \\ 0.02 & 0.589 & 77.4 & 70.5 \\ 0.05 & 0.816 & 59.4 & 85.0 \\ 0.10 & 0.914 & 45.0 & 96.2 \\ 0.20 & 0.956 & 33.6 & 88.0 \\ 0.30 & 0.968 & 29.0 & 71.2 \\ 0.40 & 0.974 & 26.7 & 55.2 \\ 0.50 & 0.976 & 25.7 & 40.5 \\ 0.60 & 0.977 & 25.0 & 28.8 \\ 0.70 & 0.980 & 24.2 & 20.7 \\ 0.80 & 0.983 & 23.2 & 14.6 \\ 0.90 & 0.989 & 21.8 & 10.5 \\ 0.85 & 0.894 & 20.9 & 8.74 \\ 1.00 & 1.000 & 18.8 & 7.43\end{array}$

Calculated at 760 mm total prossure by the mothod of Chilton and Colburn (16) 
EXPAIM RTET 


\section{ERUIPU}

All fractionations were accomplished in en experimental laborat ory column having the following spoc1f Lat Lons.

Number of plates

20 (plus robolior)

Diamet or

10 inches

Plate opacing

8 inohes

vapor risers

1-5/8 1nch d1a. (4 por plato)

Downeoners

1/2 Inch dia. (2 per plate)

wetrs

6 in. $x 1$ in. (2 por plato)

Bubble caps

$2-1 / 2$ in. ata. $\times 1-3 / 4$ in. high (4 por plato)

Slets

$5 / 8$ in. $x$ 1/8 in. (31 per cap)

Calandria (roboller)

12 1n. dia. $x 12$ in. long (sholl)

24 I In. tubes; with auxiliary

open st easn connection

Foed arrang ement

Liquid feod inlets on plates 1,3, $5, \ldots . .-15,17$ (from top)

Vapor foed inlots on plates 2, 4, $6, \ldots . . .18,20$ (Irom top)

Liquid feed dellvered by goar pump through a rotaneter

Foed pot 60 gallon capacity 
Overhead:

Sampling

Temperat uros

Two cond ons ors (tube and hell)

splitter box arranged to deliver any desired portion of overheads

as roflux to top plate

Produet and rorlux flow by

gravity through rotameters

Bamplo cocks arranged to produce samples of the liquid off plates

$1,3,5, \ldots 17,18$

samples of feed, waste, and orerheads oaily obtainable Plato temperatures obtalned by coppor-constantan thermocouples In the Ilquid on plates 1 thru 20 The column wa designed for a maximum foed rate of twonty gallons por hour, and for satiafactory oporation on tho syotems othanol-water, benzeno-toluene, and acotio ac1d-water at vapor velocities between 0.75 and 1.25 feet per second. (A sketch of the colume and detalls of plate construction are ahow in Figures 14 and 15, Appendix.)

\section{SYSTEAS IUVESTIOATKD}

The first sy st en st udiod was et hanol-wat or, chosen because the oporation of the column with this system had 
boon studied and proved dependable. The ayotem ylelded viscosity-velat1lity preducts in the central pertion of the range to be inveat lgated; and it afforded excellent opport unitios to become familiar with tho operating varlables of the colum. Add od foatures with rospect to the correlation were the incluaion of a syon producing a constant bolling mixturo, and tho ease in analysis. The samples wero analyzed by Westphal Balance denalty noasurementa and density-cpmposition data for ot hanolwater mixturea in standard reforences. The precialon for the analyses was 0.2 mol per cent.

The of st en mothanol-wat or was chosen in order to expand the correlation in the central portion of the viscosity-relatility product range. The viscosityvolatility preduct for nothanol-water was essont lally the same as that for ethanel-wat or; however, the preduct was obtained by lower viscosity and higher relative velatility. Agaili, the case in analyeis was a contributing factor. Hethanel-wat or mixtures were analyzed by Westphal balance density moesur oments in conjunction with densitycomposition data in standard reforences. The procision was 0.2 mol por cent."

Benzene-toluene was chosen as the third ayst om to be studied for one major reacon - - this syotom, widely roported in the lit orature, offerod a means of comparing 
the oporating oharact oriatiof of the equipment to the characteristics of oquipment usod by other Investigators. The syst ex, in addition, oxt ond ed the range in viscosityvelatility pred uet beyond that covered by the two previous syst oms. Diffloulty in analysis was ovaroome by the following procedure: For those samplos low in tolupo cont ont. Iroezing point doterminationg lod to analyses with a procision of 1.0 mol per cont. Satisfactory rosults for the 10 bonsene samples were obtalned by vapor pressure mesaurements as outilned by Fat elsova and Zuckermann (18). Through careful uae of this method, a precintion of $0.5 \mathrm{~mol}$ per cont was ebtalned. The precision of elther method was unsatiefactory for amplos of liquid in the central portion of tho colum, and, rathor than inolude results of doubtful validity, colum offleleneles only nere reported for benzene-toluene fract ionations.

The sy stem carbon tetrachloride-bensene off ored the inelusion of a relative volatility which was very lew, filling in the lower portion of the viscosity-volatility product range. The add ed reature of ignifleance was the fact that the waterial of higher density wa being driven toward the top of the colum. Wostphal Balaned densit measur oments wore sufficlent te jield andysos with a precieion of 0.2 mol por cent. Acotald ehyde-mater, the final gystem studied 
was choson for 1t: high relative velatility to comploto the desired range in viscosity-volatility produet. It also added one more type of material to the correlation. Analyses wore by Westphal Balanco density measurements. since the density-o omposition curve contalns maximum value, it was necessary, in caser of ambigulty, to use the plate temperature in confunction with the density as measured. Preolsion for these anelyses was excellent in the high aldehyde amples, but was of the order of 2 to 3 mol per cont in the low aldohyde range. Litt lo date were obtained for this system, ince decomposition, suffiolent to produce an immiseible layor, occurred after throe or four operations.

\section{OPERATINO PROCEOURE}

Materlal from the feed pot nas pumped to the top portion of the column and allowed to flow down the column. When the liquid level in the rebolior was sufficlent, at eam was admittod to the calandria and feed was discontinued. Partial diatribution of the components nas attained as rapors rose in the column, heating the ontire column to operating temperature. All of the distillat was returned to the column as liquid roflux and tho column was allowed to approach equilibrium operating conditions. At this time, distribution in the column was adjust od by the addition of 
feed and the removal of elther distillate or waste. Plate compositions were ostimated by the liquid temperature on each plate. When the desired distribution was reached, the column was oporated at total reflux for sufficlent time to establish oquilibrium operating conditions. The approsch to conatant conditions was followed by observing plate temperatures at ton to fifteen minute intervals, When operation was essentially constant, liquid samples woro Nitharawn from alternate plates $(2,3,5, \ldots 17,19)$ and from the distillate and roboller. Plate temperatures wore recorded as well as other data.required for calculations. A sample data sheet for total reflux operation 1s presented in Figure 3.

Continuous foed was introduced at metered rate onto the plate most nearly contalning the same mixt ure as the foed mixture. The distillate was split into reflux and product at a product rate represent ing 70 to 95 per cont of the low bolling component entering in the rood. The bottoms dran-off was adjustod to maintain a constant liquid level in the reboller. Cont inuous reed, product, and bottoms retes were carefully controlled for a pertod sufficlent to produce congtant operation as Indleated by oonstant plate temperatures. Samples and data were obteined as during total reflux, with the adition of a feed sample and feed and product flow rates. The 
bottons rate was not metered; but it was asumed that maintaining constant feed and product rates and o constant 11quid level in the reboller vould cause the bottons rate to be equal te the differene between the foed rate and the product rate. This adjustment required that colume holdup be essent 1ally constant - - which should occur under normal operating conditions. Typlcal data sheots for continuous operations are presented in Pigures 4, 5, 6, and. Tro mothod were uaed to effect ohange in reflux rat 10:

(1) Feed and product rates wore held constant wh110 changing the heat input to the reboller.

(2) Heat laput to the rebeller was held constant whilo changing feed and/or product rates. Samples for total reflux and continuous operations wero analyzed by the methods proviously deseribed. 
DATA AMD RESULTS 
Typical data sheets for operatione are presented

In Figures $3,4,5,6$, and 7 . Figure 3 is the date -btalned during one operation at total reflux using the systen othanol-water. The other data presented, Figure 4, 5, 6, and 7, ropresent one cont inuous operation for each of the systens methanol-water, benzene-toluene, carbon tetrachloride-benzene, and acetaldehyde-wat or respectively. Complete data are contained in original research notes on f1le with the Institute of Induatrial Research, Oniversity or Loulavilie.

Results aro present ed in tabular forn for cach syat em Investigated (Tables VI, VII, VIII, IX, and X). An explanation of the tablos follows:

Rum number

The number assigned to any pertioular operation in the original notes

Number or Plates

The number of actual plates in the section of the column considered over which the data were of sufflolont aocuracy to use in caleviations - - not nocessar1ly the number of plates botween foed and product or foed and wasto (this approach oliminates Including a mis-matohed rood seotion in calculations) Vapor Velocity

The superficlal vapor veloeity in the column, based on overhesd measurements and corrected for temporat ure 


\section{Syst on: Bt hanol-wat or \\ (Total Reflux)}

Run Ho. 7

Date: 7 June, 1946

Feed to plate 25 Q 10:00 A.M.

St cam to calandria $10: 15$ A.M.

Rerlux over @ 11:00 A.M.

Temperatures Indicate too little othanol in colum

added 1 gallon othanol to roflux $11: 25 \mathrm{~A} . \mathrm{M}$.

Samples and temperat ures 12:10 P.M.

Sample sp. Or.

Uel \& othanol

Plato Temp. ${ }^{\circ} \mathrm{C}$.

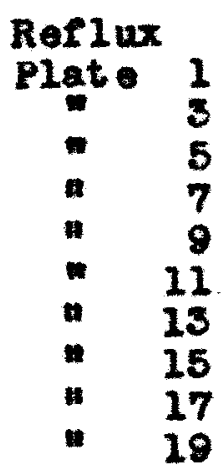

Bettoms

0.8106

0.8127

0.8188

0.8256

0.8415

0.8981

0.9896

0.9962

0.9965

0.9965

0.9965

0.9965

Steam prossure:

8 ps 1 ga.

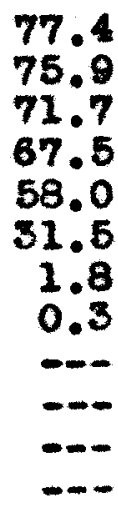

77.4

75.9

67.5

58.0

31.5

1.8

0.3

-.-

$\cdots$

$\cdots$

$\begin{array}{ll}1 & 78 \\ 2 & 78 \\ 3 & 78 \\ 4 & 78 \\ 5 & 78.5 \\ 6 & 79 \\ 7 & 79.5 \\ 8 & 80.5 \\ 9 & 83 \\ 10 & 90 \\ 11 & 96 \\ 12 & 98 \\ 13 & 99.5 \\ 14 & 100 \\ 15 & 100 \\ 16 & 100 \\ 17 & 100 \\ 18 & 100 \\ 10 & 100 \\ 20 & 100\end{array}$

Rorlux rotameter: $55 \mathrm{~mm} 35^{\circ} \mathrm{C}$. Rate: $120 \mathrm{lbs} . / \mathrm{hr}$.

Plgure 3: Typical Data Shoot for bthanol-liater 
Syatom: Methanel-Water

(Cont Inuous Operation)

Run No. 21

Date: 18 June, 1946

Colum brought to oquilibrium in run no. 10

Feed to plate $13 \odot 12: 10$ A.M.

Product and bottoms over $11: 15$ A.M.

Samples and temperatures@12:15 P.M.

Sample Sp. Cr. Mol \% methanol Plate Tomp. ${ }^{\circ} \mathrm{C}$.

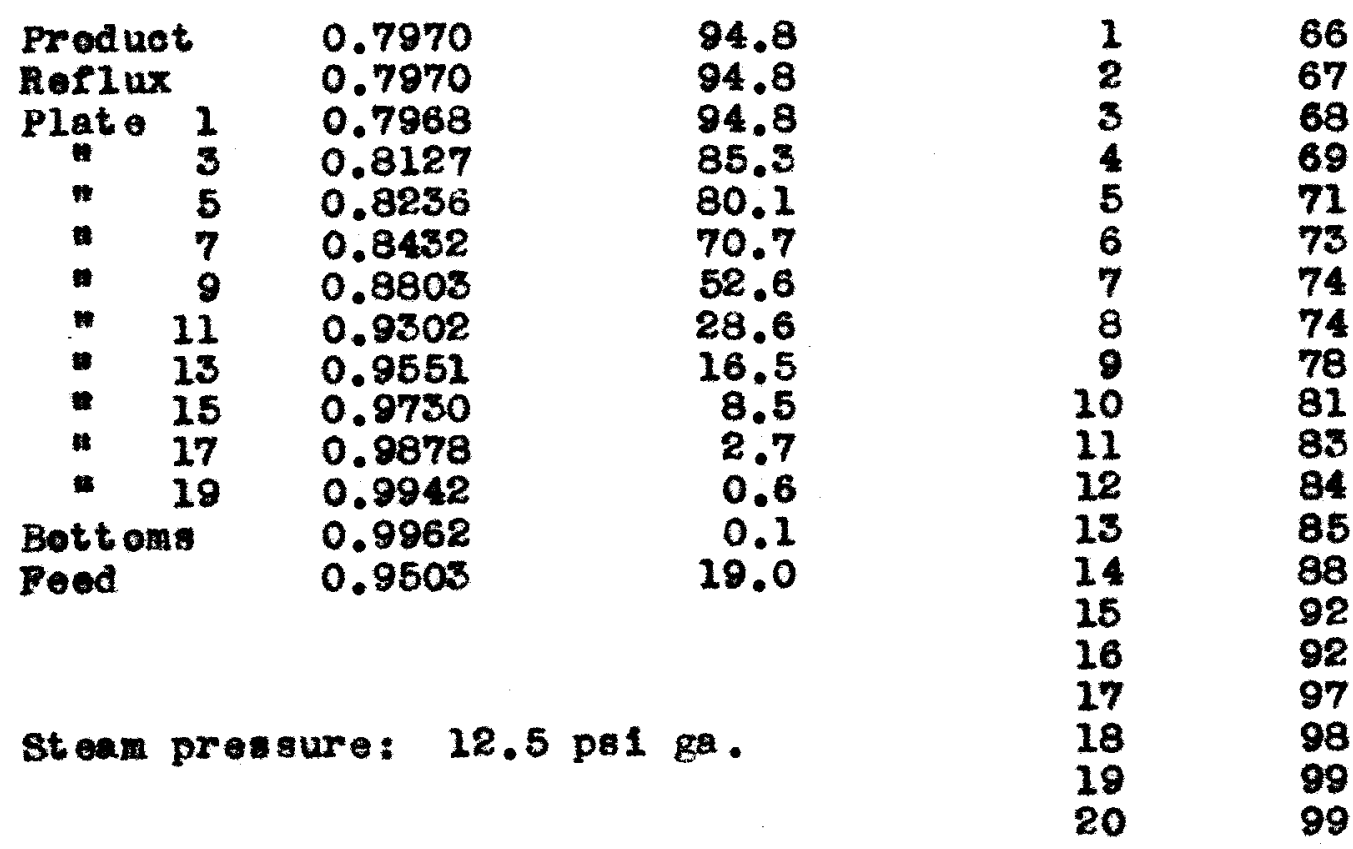

Feed rotaneter: $200 \mathrm{~mm} @ 60^{\circ} \mathrm{C}$. Rate: $115 \mathrm{lba} . / \mathrm{hr}$. Product rotameter: 45 mm $95^{\circ} \mathrm{C}$. nate: $391 \mathrm{ba} . / \mathrm{hr}$. Reflux rotameter: $28 \mathrm{~mm} 35^{\circ} \mathrm{C}$. Rate: $66 \mathrm{lbs} . / \mathrm{hr}$.

Mgire 4: Typlcal Data sheet for Methanol-Vator 


\section{Syst en: Benzene-Teluene}

(Cont inuous operation)

Run No. 24

Dete: 11 oet.. 1846

column brought to oquilibrium in run no. 23

Peod. to plate 13 12:15 P.M.

Preduct and bettons orer $12: 20$ P.M.

samples and temperatures 1:30 P.M.

Semple Method of Mol 8 bonzene plat Temp. $C$. Ana $2 y=18$

Produot Froezing point 99

Reflux

Plate 1

" "

- 7

- 9

- 11

- 13

- 15

- 17

- 19

Bott oms

Feed

Vepor Pressure

4

$\boldsymbol{n}$

E

I.

i.

a

t)

-

n

99

99

99

96

94

88

65

47

38

28

20

9

32

Stoum prossure: 22 pal ga.

9
99
9
9
6
4
8
7
8
8
0
9
32

280

280

301

482

$5 \quad 82$

$6 \quad 82$

782

$8 \quad 82$

983

$10 \quad 84$

1185

$12 \quad 87$

13.90

1491

1594

1694

$17 \quad 97$

1898

$19 \quad 101$

$20 \quad 103$

Food rotameter: $200 \mathrm{~mm} 965^{\circ} \mathrm{C}$. Rate: $100 \mathrm{lbs} . / \mathrm{hr}$. Product rotameter: $42 \mathrm{~mm} 35^{\circ} \mathrm{C}$. Rate: $331 \mathrm{bs} / \mathrm{hr}$. Reflux rotameter: 120 (a) $35^{\circ} \mathrm{C}$. Rate: $163 \mathrm{lbs} . / \mathrm{hr}$.

Figure 5: Typlcal Data Sheet for Benzene-Toluene 
Syst om: Carbon Tetrachloride-Benzene

(Cont Inuous operation)

Run No. 33

Dat e :

21 Nov. 1946

Celumn brought to equilibriun in run no. 32

Food to plate 5 10:30 A.M.

Product and bottoms ovor 10:35 A.M.

Samples and temperatures@ 11:30 A.M.'

Semplo Sp. Or. Mol $\% \mathrm{CCl}_{4}$ Plate Temp. $\mathrm{C}$.

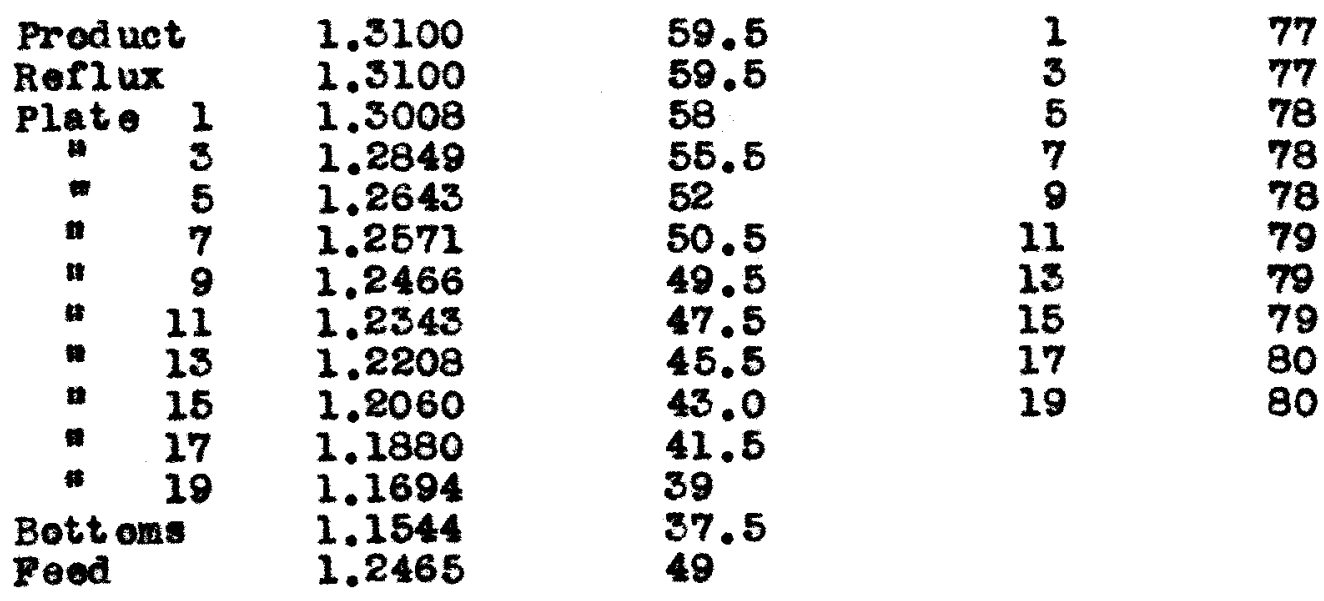

Steam pressure: 4 pel ga.

Foed retamoter: 175 man $40^{\circ} \mathrm{C}$. Rate: $114 \mathrm{lbs} . / \mathrm{hr}$. Product rotameter: 40 40 $40^{\circ} \mathrm{C}$. Rate: $72 \mathrm{lbs} . / \mathrm{hr}$. Reflux rotameter: $215 \mathrm{~mm} 40^{\circ} \mathrm{C}$. Rate: $460 \mathrm{lbs} . / \mathrm{hr}$.

Pigure 6: Typleal Data Sheet for Carbon Tetrachlorido-Benzene 
Syet em: Aeetaldehyde-Int or

(Cont Inuous Operation)

Run No. 47

Date: 17 Jan. 1947

Column brought to oquilibrium in run no. 46

Feed to plate 9 11:50 A.H.

Product and bottoms over e 12:00 1.

Samples and temperatures 12:40 P.M.

Sample Sp. Er. Mol \& aldehydo Plate Temp. ${ }^{\circ}$.

Product $\quad 0.7960$

Rerlux $\quad 0.7960 \quad 99.5$

Plete $19.7985 \quad 98.2$

- $3 \quad 0.8009 \quad 97.5$

n $5 \quad 0.8040 \quad 96.0$

1. 70.8087

- $\quad 0.9896$

. $11 \quad 1.0116$

- $13 \quad 2.0012$

43.5

34.8

- $15 \quad 1.0020$

0.6

0.8

1.0013

0.6

0.6

- $19 \quad 1.0015$

1.2

Bottoms

1.0028

Feed

1.0212

29.3

$\begin{array}{ll}1 & 21 \\ 2 & 21 \\ 3 & 21 \\ 4 & 21 \\ 5 & 21 \\ 6 & 21 \\ 7 & 22 \\ 8 & 24 \\ 9 & 26 \\ 10 & 28 \\ 11 & 33 \\ 12 & 37 \\ 13 & 75 \\ 14 & 94 \\ 15 & 100 \\ 16 & 100 \\ 17 & 100 \\ 18 & 100 \\ 19 & 100 \\ 20 & 100\end{array}$

Foed rotameter: 175 ma $20^{\circ} \mathrm{C}$. Rate: $105 \mathrm{lbs} / \mathrm{hr}$. Product retanet er: $50 \mathrm{~mm}$ (8) $20^{\circ} \mathrm{C}$. Rate: $421 \mathrm{bs} . / \mathrm{hr}$. Reflux rotameter: $30 \mathrm{~mm}$ (20\% $0^{\circ} \mathrm{Rate:} 63 \mathrm{lbs} / \mathrm{hr}$.

P1gure 7: Typ1cal Data Shoot for Acetaldehyde-Wat or 
Table VI: Result for Fthanol-Water Fractionations

\begin{tabular}{|c|c|c|c|c|c|c|c|c|c|c|c|c|}
\hline $\begin{array}{l}\text { Run } \\
\text { Io. }\end{array}$ & Section & $\begin{array}{l}\text { Ho, or } \\
\text { Plat es }\end{array}$ & $\begin{array}{l}\text { Vapor } \\
\text { Veloo } 1 t y\end{array}$ & $I / V$ & $\mathbf{X} n$ & $x_{n}$ & $\begin{array}{l}\text { Theo. } \\
\text { Plates }\end{array}$ & $\begin{array}{c}\text { Overall } \\
\text { Eef. }\end{array}$ & $\begin{array}{l}\text { Avg.t } \\
\text { Deg.c }\end{array}$ &.$\mu$ & $\alpha$ & $\mu 0$ \\
\hline 1 & Col unn & 8 & 0.60 & 1.00 & .013 & .693 & 3.63 & 45.4 & 84 & .60 & 2.4 & 1.44 \\
\hline 2 & Column & 8 & 1.04 & 1.00 & .011 & .676 & 3.50 & 43.8 & 86 & .60 & 3.0 & 1.80 \\
\hline 3 & Column & 4 & 0.58 & 1.00 & .022 & .498 & 2.00 & 47.6 & 90 & .60 & 3.1 & 1.86 \\
\hline 6 & column & 8 & $0.8 B$ & 1.00 & .008 & .700 & 3.88 & 48.6 & 87 & .60 & 3.0 & 1.80 \\
\hline 7 & Colum & 10 & 0.71 & 1.00 & .018 & .750 & 4.72 & 47.8 & 83 & .59 & 1.9 & 1.11 \\
\hline 8 & Column & 10 & - & 1.00 & .002 & .740 & 5.25 & 52.5 & 86 & .60 & 2.6 & .56 \\
\hline 9 & Rect. & 6 & 1.09 & 0.91 & .046 & .675 & 3.05 & 50.8 & 84 & .60 & 2.5 & .50 \\
\hline
\end{tabular}


Table VII Result for Hethanel-nater Fractionations

\begin{tabular}{|c|c|c|c|c|c|c|c|c|c|c|c|c|}
\hline $\begin{array}{l}\text { Run } \\
\text { No. }\end{array}$ & Section & $\begin{array}{l}\text { No. of } \\
\text { Plat os }\end{array}$ & $\begin{array}{l}\text { Vapor } \\
\text { Volooity }\end{array}$ & $\mathbf{L} / \mathbf{V}$ & $x_{m}$ & $x_{\mathbf{n}}$ & $\begin{array}{l}\text { Theo. } \\
\text { Plates }\end{array}$ & $\begin{array}{c}\text { Ovorall } \\
\text { Efe. }\end{array}$ & $\begin{array}{l}\text { Avg.t } \\
\text { Dog.c. }\end{array}$ & $\mu$ & $\alpha$ & $\mu \mathrm{c}$ \\
\hline 20 & Colunn & 8 & 1.07 & 1.00 & .075 & .255 & 4.20 & 52.5 & 73 & .37 & 3.2 & 1.18 \\
\hline 11 & $\begin{array}{l}\text { Column } \\
\text { Reot. } \\
\text { Strip. }\end{array}$ & $\begin{array}{r}18 \\
10 \\
6\end{array}$ & \begin{tabular}{c}
0.76 \\
\hdashline..- \\
$-\cdots$
\end{tabular} & $\begin{array}{l}0.63 \\
\ldots . .- \\
\cdots-.\end{array}$ & $\begin{array}{l}.006 \\
.286 \\
.006\end{array}$ & $\begin{array}{l}.948 \\
.948 \\
.265\end{array}$ & $\begin{array}{l}9.15 \\
4.67 \\
3.58\end{array}$ & $\begin{array}{l}50.9 \\
46.7 \\
58.6\end{array}$ & $\begin{array}{l}81 \\
73 \\
93\end{array}$ & $\begin{array}{l}.35 \\
.36 \\
.89\end{array}$ & $\begin{array}{l}3.8 \\
3.1 \\
6.8\end{array}$ & $\begin{array}{l}1.33 \\
1.18 \\
2.00\end{array}$ \\
\hline 12 & $\begin{array}{l}\text { Column } \\
\text { Rect. } \\
\text { Strip. }\end{array}$ & $\begin{array}{r}24 \\
6 \\
2\end{array}$ & \begin{tabular}{l}
0.73 \\
\hdashline.--
\end{tabular} & $\begin{array}{c}0.81 \\
\cdots \\
\cdots\end{array}$ & $\begin{array}{l}.009 \\
.350 \\
.009\end{array}$ & $\begin{array}{l}.016 \\
.016 \\
.058\end{array}$ & $\begin{array}{l}5.90 \\
8.95 \\
1.16\end{array}$ & $\begin{array}{l}42.1 \\
49.2 \\
57.8\end{array}$ & $\begin{array}{l}84 \\
73 \\
96\end{array}$ & $\begin{array}{l}.34 \\
.36 \\
.30\end{array}$ & $\begin{array}{l}4.2 \\
3.1 \\
7.7\end{array}$ & $\begin{array}{l}1.43 \\
1.12 \\
2.31\end{array}$ \\
\hline 14 & $\begin{array}{l}\text { Column } \\
\text { Reot. } \\
\text { strip. }\end{array}$ & $\begin{array}{r}12 \\
6 \\
2\end{array}$ & $\begin{array}{l}1.16 \\
-\ldots .-\end{array}$ & $\begin{array}{c}0.82 \\
--.- \\
\cdots--\end{array}$ & $\begin{array}{l}.006 \\
.163 \\
.006\end{array}$ & $\begin{array}{l}.885 \\
.885 \\
.035\end{array}$ & $\begin{array}{l}5.61 \\
3.22 \\
1.15\end{array}$ & $\begin{array}{l}46.8 \\
58.6 \\
57.8\end{array}$ & $\begin{array}{l}84 \\
75 \\
97\end{array}$ & $\begin{array}{l}.35 \\
.37 \\
.30\end{array}$ & $\begin{array}{l}4.5 \\
3.4 \\
8.0\end{array}$ & $\begin{array}{l}1.58 \\
1.26 \\
2.40\end{array}$ \\
\hline 25 & Reet. & 4 & 1.16 & 0.87 &. .188 & .783 & 2.09 & 52.2 & 68 & .30 & 3.6 & .40 \\
\hline 17 & $\begin{array}{l}\text { Col unan } \\
\text { Reot. } \\
\text { strip. }\end{array}$ & $\begin{array}{r}10 \\
6 \\
4\end{array}$ & 0.63 & $\begin{array}{l}0.85 \\
-. .- \\
-\cdots\end{array}$ & $\begin{array}{l}.005 \\
.143 \\
.005\end{array}$ & $\begin{array}{l}.875 \\
.875 \\
.143\end{array}$ & $\begin{array}{l}5.23 \\
2.97 \\
2.26\end{array}$ & $\begin{array}{l}52.3 \\
49.4 \\
56.5\end{array}$ & $\begin{array}{l}82 \\
75 \\
95\end{array}$ & $\begin{array}{l}.29 \\
.36 \\
.30\end{array}$ & $\begin{array}{l}4.2 \\
3.5 \\
7.6\end{array}$ & $\begin{array}{l}.82 \\
.26 \\
.28\end{array}$ \\
\hline
\end{tabular}


Table VIII: Reaults for Benzene-Toluene Practionstions

\begin{tabular}{|c|c|c|c|c|c|c|c|c|c|c|c|c|}
\hline $\begin{array}{l}\text { Run } \\
\text { Ho. }\end{array}$ & Secti on & $\begin{array}{l}\text { Mo. of } \\
\text { Plat os }\end{array}$ & $\begin{array}{l}\text { Vapor } \\
\text { Velocity }\end{array}$ & $L / V$ & $\mathbf{X m}$ & $x_{n}$ & $\begin{array}{l}\text { Theo. } \\
\text { Plates }\end{array}$ & $\underset{\text { Bef. }}{\text { Overal1 }}$ & $\begin{array}{l}\text { Avg.t } \\
\text { Deg.C. }\end{array}$ & $\mu$ & $\alpha$ & $\mu c$ \\
\hline $28(a)$ & Column & 28 & 0.50 & 1.00 & .005 & .98 & 20.5 & 58 & 91 & .29 & 2.46 & .715 \\
\hline 21 & Column & 18 & 0.21 & 2.00 & .005 & .98 & 10.5 & 88 & 92 & .29 & 2.46 & .715 \\
\hline 28 & Column & 28 & 0.70 & 0.78 & .07 & .05 & 10.6 & 59 & 80 & .29 & 2.46 & .716 \\
\hline 23 & Colman & 14 & 0.49 & 1.00 & .09 & .89 & 7.8 & 56 & 90 & .28 & 2.49 & .895 \\
\hline 24 & Colum & 14 & 60 & 0.83 & .20 & .86 & 7.0 & 50 & 89 & .28 & 2.48 & .695 \\
\hline 25 & column & 24 & 0.56 & 1.00 & .22 & .98 & 6.5 & 46 & 90 & .28 & 2.49 & .695 \\
\hline 26 & Column & 14 & 0.18 & 0.86 & .21 & .84 & 7.0 & 50 & 92 & .29 & 2.46 & .718 \\
\hline
\end{tabular}


Table IX: Result for Carbon Tetraohloride-Benzene Frect ionatione

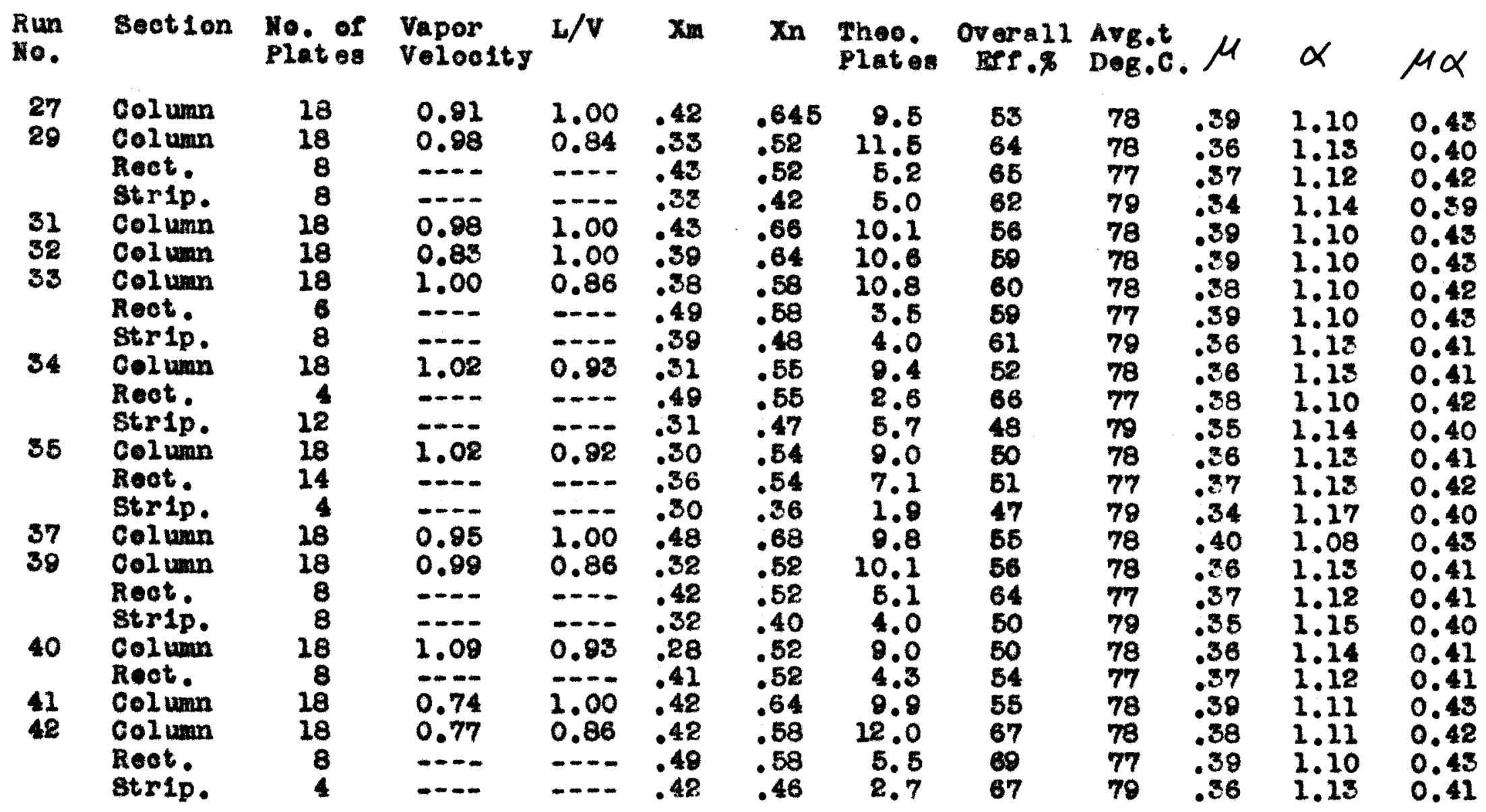


Table X: Reault o for Aoetaldohyde-Wat or Fract ionat 1 on:

\begin{tabular}{|c|c|c|c|c|c|c|c|c|c|c|c|c|}
\hline $\begin{array}{l}\text { Run } \\
\text { Slo. }\end{array}$ & Section & $\begin{array}{l}\text { Mo. of } \\
\text { Plat os }\end{array}$ & $\begin{array}{l}\text { Vapor } \\
\text { Veloo1ty }\end{array}$ & $L / V$ & $x m$ & $x_{n}$ & $\begin{array}{l}\text { Theo. } \\
\text { Plat es }\end{array}$ & $\underset{\text { Eff.x }}{\text { Overall }}$ & $\begin{array}{l}\text { Avg.t } \\
\text { Deg.C. }\end{array}$ & $\mu$ & $\alpha$ & $\mu$ \\
\hline 46 & strip. & 4 & $-\cdots$ & $\ldots$ & .005 & .305 & 1.8 & 48 & 72 & .36 & 97 & 35.0 \\
\hline 46 & Colum & 8 & 0.48 & 2.00 & .006 & .980 & 2.63 & 33 & 32 & .36 & 18 & 6.8 \\
\hline 47 & $\begin{array}{l}\text { Column } \\
\text { Root. } \\
\text { strip. }\end{array}$ & $\begin{array}{l}8 \\
4 \\
4\end{array}$ & 0.41 & \begin{tabular}{l}
0.60 \\
\hdashline..-
\end{tabular} & $\begin{array}{l}.006 \\
.435 \\
.006\end{array}$ & $\begin{array}{l}.960 \\
.960 \\
.435\end{array}$ & $\begin{array}{l}2.87 \\
1.00 \\
1.67\end{array}$ & $\begin{array}{l}35 \\
25 \\
42\end{array}$ & $\begin{array}{l}32 \\
27 \\
40\end{array}$ & $\begin{array}{l}.46 \\
.34 \\
.52\end{array}$ & $\begin{array}{l}35 \\
15.5 \\
77\end{array}$ & $\begin{array}{r}16.0 \\
5.3 \\
40.0\end{array}$ \\
\hline 48 & Column & 4 & 0.46 & 1.00 & .521 & .985 & 1.50 & 38 & 22 & .37 & 18 & 6.8 \\
\hline
\end{tabular}


$\mathbf{L} / \mathbf{V}$

The reflux ratio caloulated from orerhead measurement (samplo caloulation in Appendix)

$\mathbf{X}$

Mel fraotien of the low bolling component in the liquid off the bottom plate of the section und or cons 1d erat ion

$\operatorname{xn}$

Hol fraction of the low bolling component in the Ilquid Into the top of the section under consideration Theorotieal Plates

Number of theoretical (equilibrium) plates required to Gririoh from $X_{m}$ to $X_{n}$ (anplo calculation in Appendix) orerall Brflolency Por cent

The ratio of theoretical to actual number of plates roquired to onrich from $X m$ to $X n$ (amplo caloulation In Append (x)

Average romperat ure Degrees $C$. The average temperat ure of the Iiquid on the plates boing considerod

$\mu$

The peuede molal viscesity of the liquid in the section of the celum under conelderation at the average temperature and composition (sample caloulation in Appond (x) 
$\alpha$

The relative velatility at the average composition of the liquid in the section

$\mu \alpha$

The product of the viscosity and the relative volatility (v1scosity-volat111ty product)

Complet mothods used for obtaining calculat ed results are present ed in the Appendix. The report ed officieneios aro considered apresentation of the best data obtained in any given section of the column, disregarding all data apparentig in orror due to operational or analytical discrepaneles.

The overall efficiencios are presented as a function of the viscosity-volatility product in Figures 8, $9,10,11$, and 12. The correlation proposed by $0^{\prime}$ Connell (14) is included with the data obtained since the original problem was an evaluation of this correlation. Figure 8 presonts officlencies obtained for all systems during total reflux operation. Figures 9,10 , and 11 present col um, rectifier, and stripper officlencies, respectively, for all systems during continuous operation. In Table XII, the section and column efficiencles were averaged for each system in order to minimize the effect of errors due to individual operational discrepancies. The average results are plotted in Figure 12. 


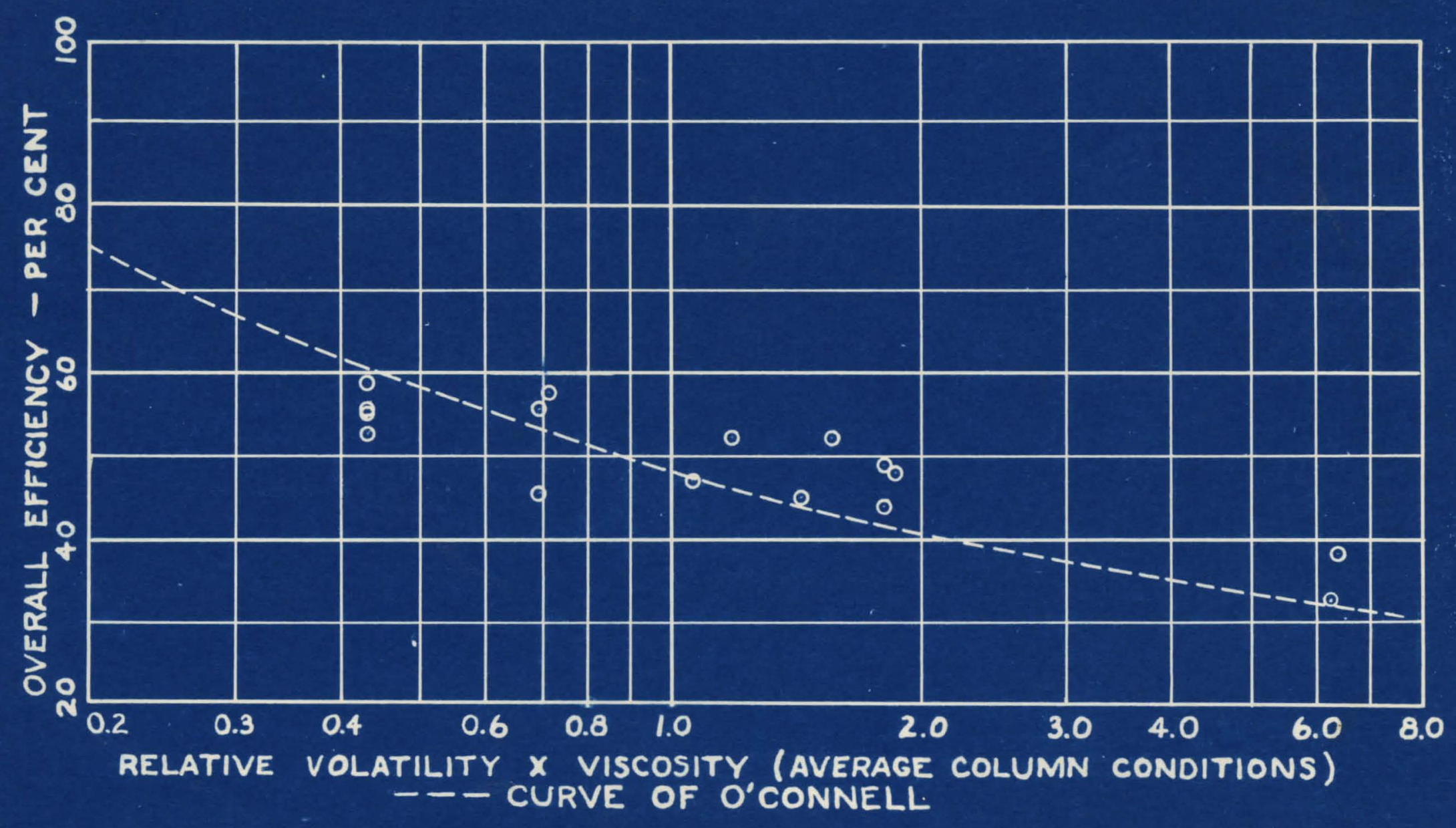
FIG. 8 - EFFECT OF RELATIVE VOLATILITY AND VISCOSITY ON OVERALL EFFICIENCY
(TOTAL REFLUX OPERATIONS)




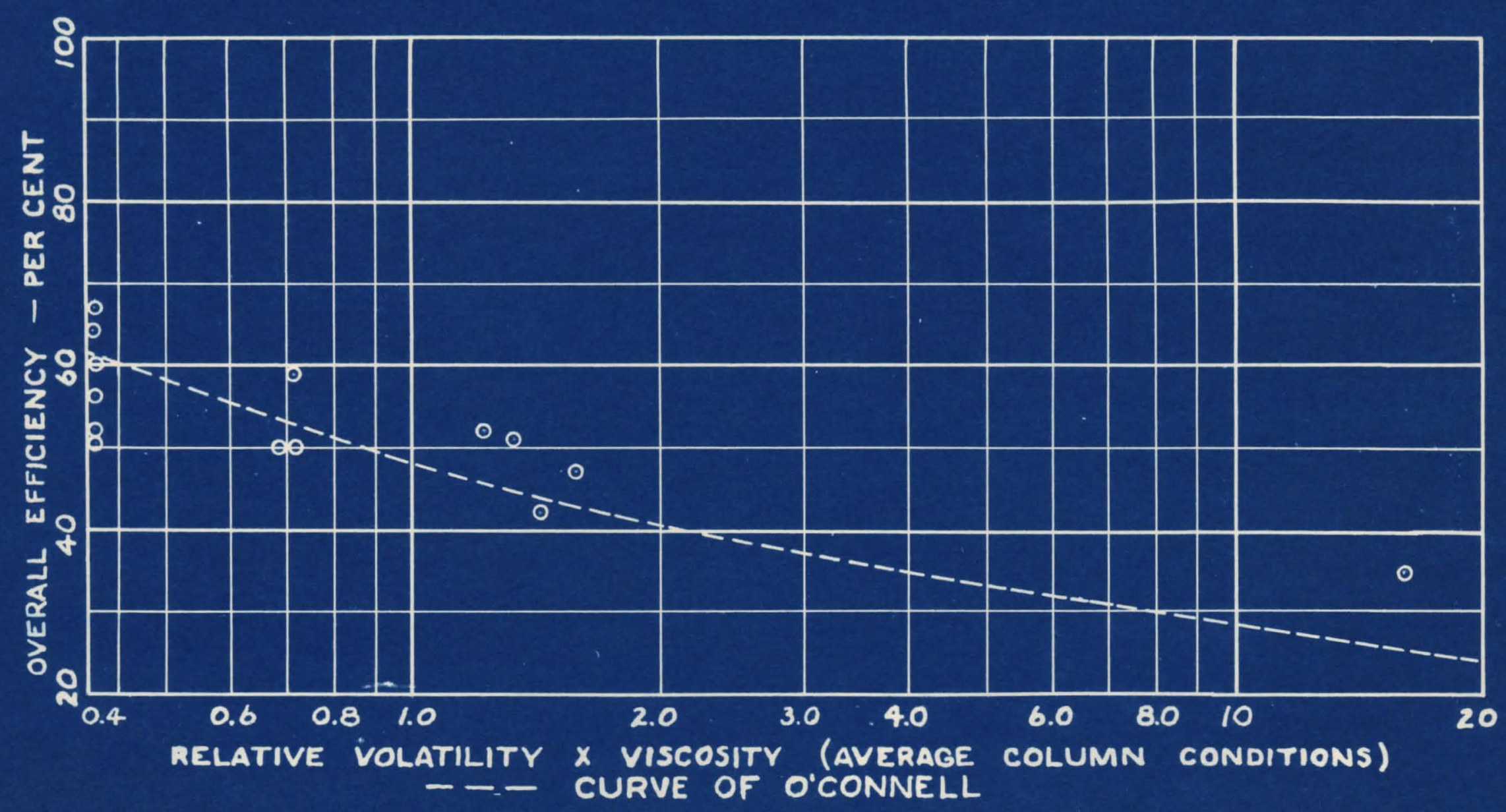

FIG. 9 - EFFECT OF RELATIVE VOLATILITY AND VISCOSITY ON OVERALL EFFICIENCY (CONTINUOUS OPERATION - COLUMN) 


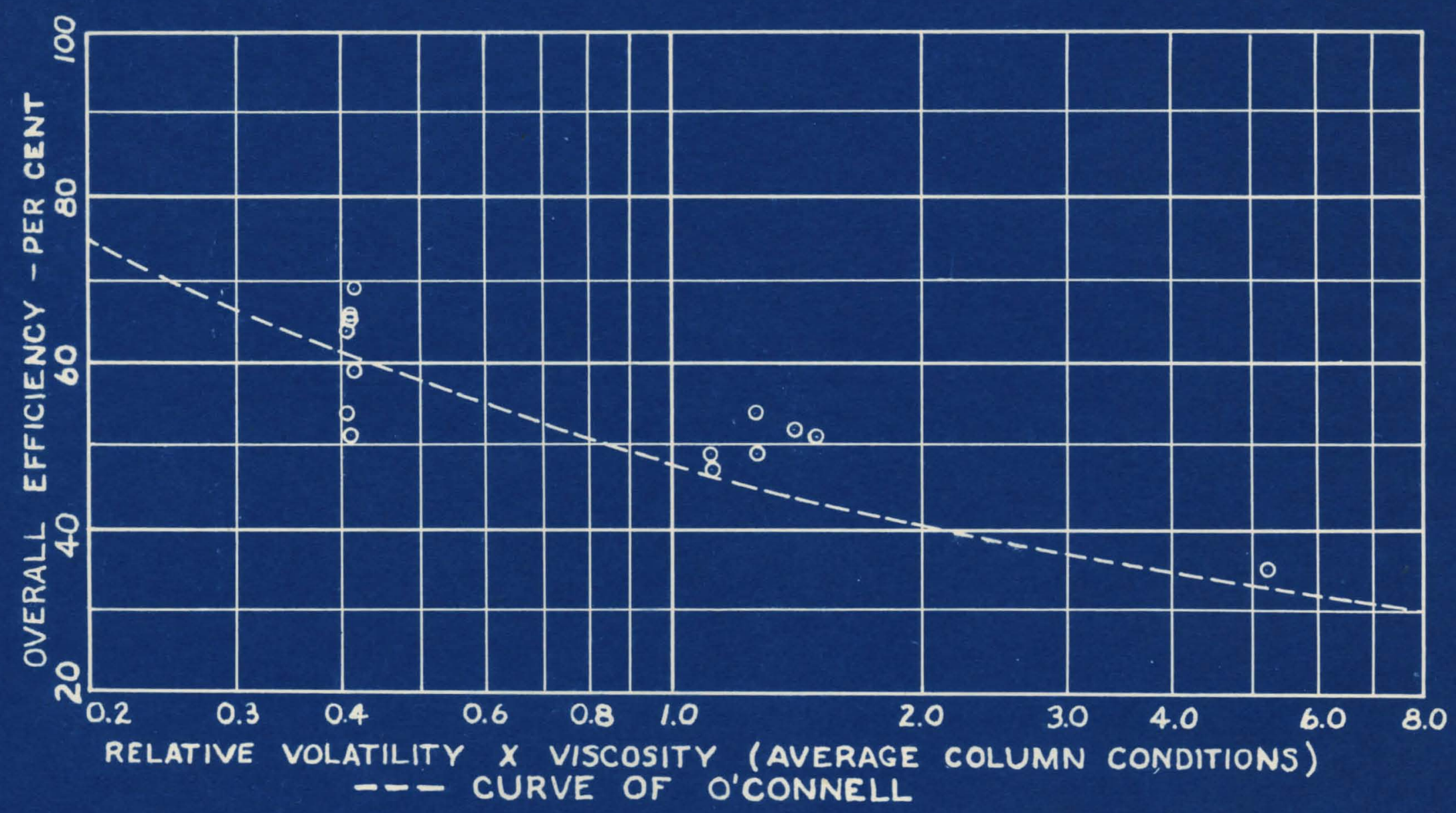

FIG. 10 - EFFECT OF RELATIVE VOLATILITY AND VISCOSITY ON OVERALL EFFICIENCY (CONTINUOUS OPERATION - RECTIFIER) 


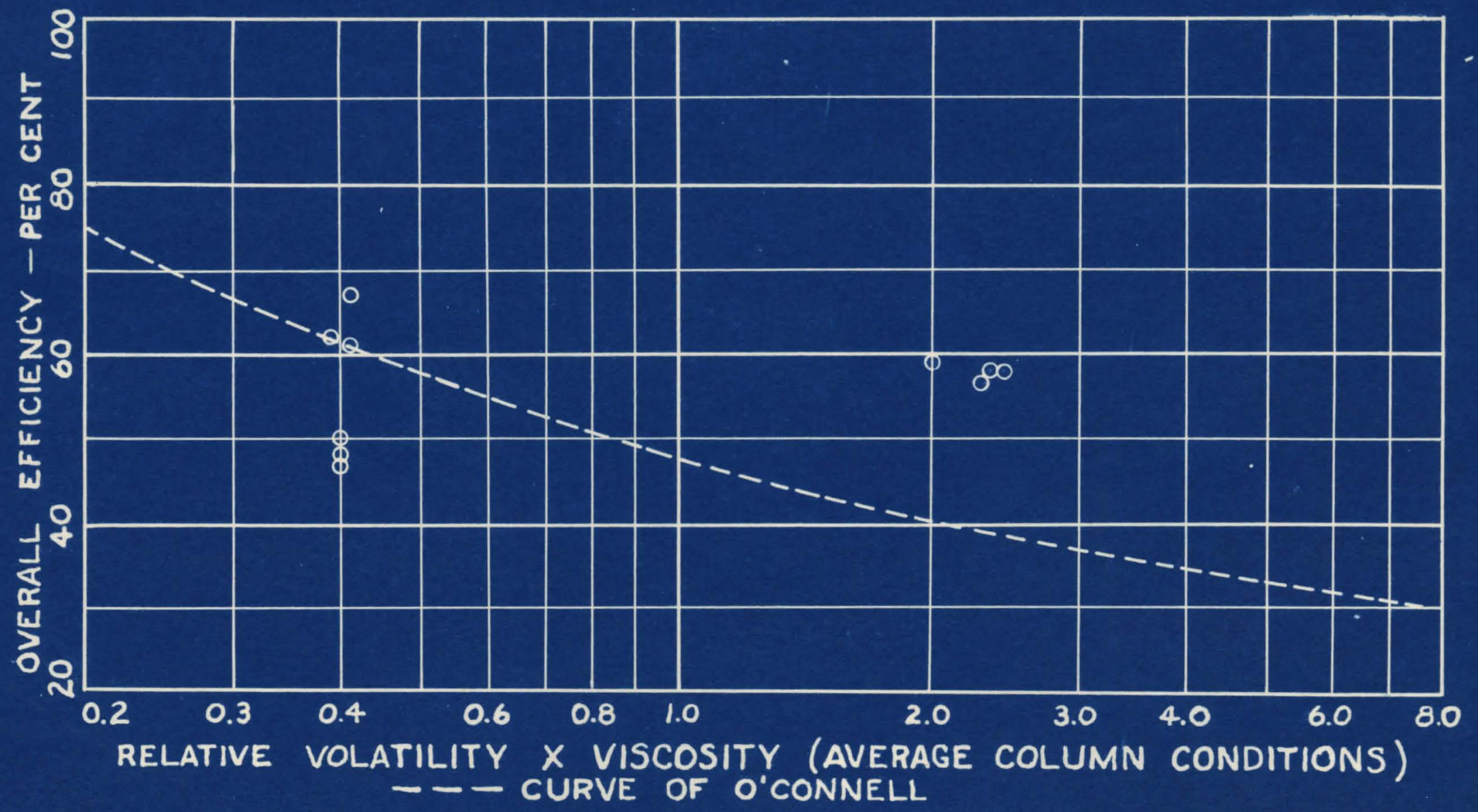

FIG. II - EFFECT OF RELATIVE VOLATILITY AND VISCOSITY ON OVERALL EFFICIENCY (CONTINUOUS OPERATION - STRIPPER) 
Table XI: Average Results by Systems (Data for Figure 12)

Syet em Total Rerlux Col unn Bff. $\% \alpha \alpha$

Ethanol-

mat or

$$
47 \quad 1.60
$$

MethanolWat or

$52 \quad 1.18$

Benzene-

Toluene $54 \quad 0.70$

Carbon tet.-

Benzene $56 \quad 0.43$

Acotaldenyde-

Wat or $36 \quad 6.45$
--D---Cont Inuous

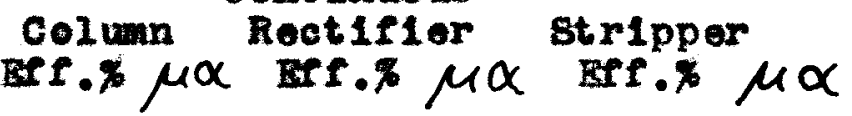

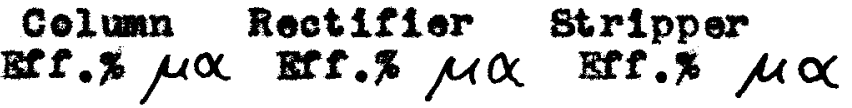

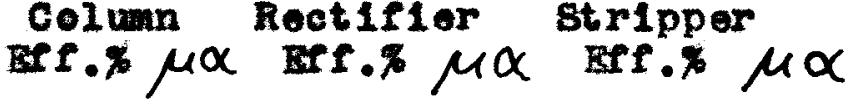

$51 \quad 1.50$

48

$$
1.3950
$$

1.23

$58 \quad 2.25$

$$
0.71
$$

$\begin{array}{lll}57 & 0.41 & 61\end{array}$

0.42

54

0.40

$\begin{array}{lll}35 & 16.0 & 25\end{array}$

42 40.0 


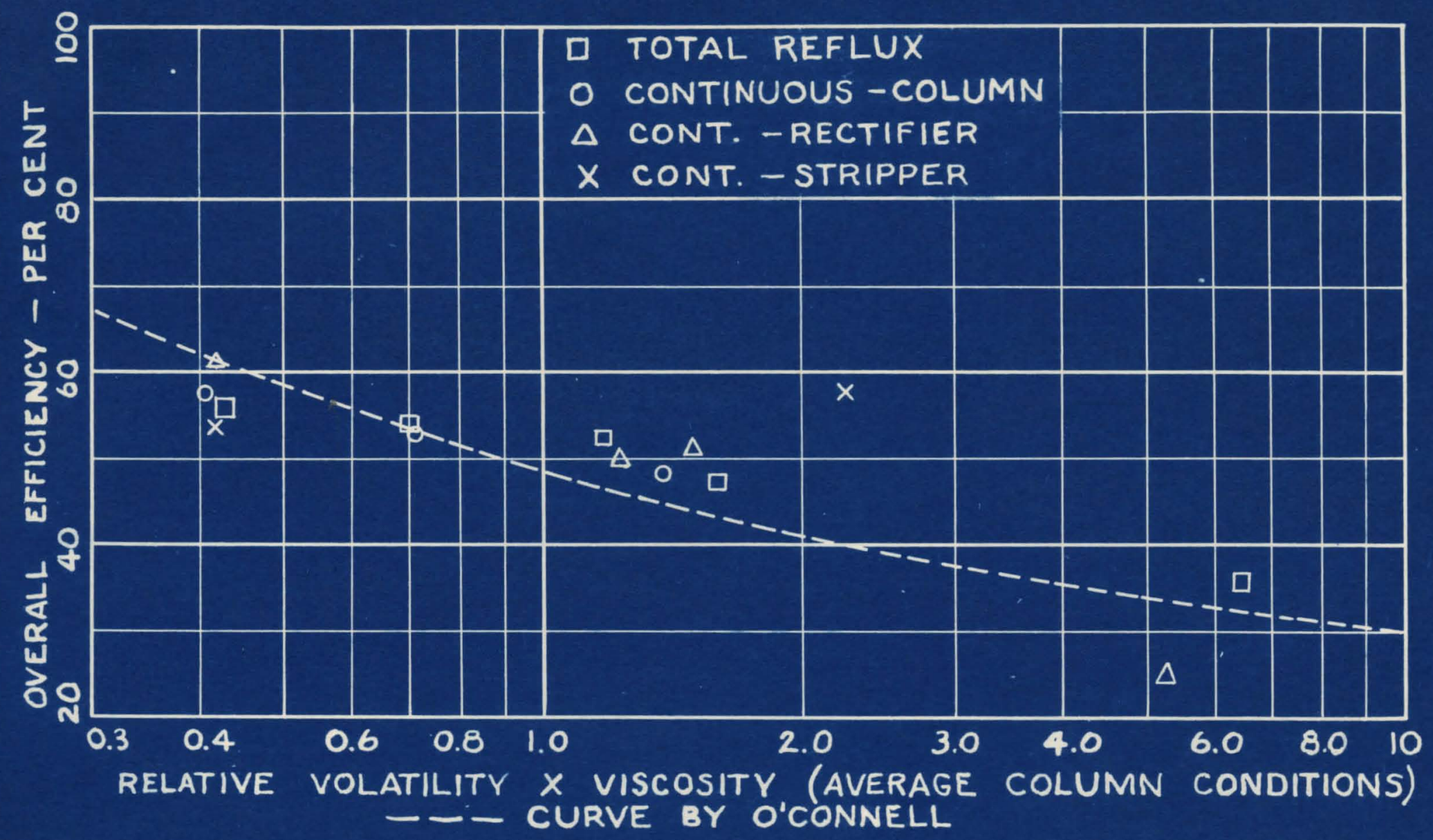

FIG. 12-EFFECT OF RELATIVE VOLATILITY AND VISCOSITY ON OVERALL EFFICIENCY (AVERAGE RESULTS BY SYSTEMS) 
DISCUSSION OP RESULTS 
Por the purpose of diseussion, deviations from the proposed correlation have been caloulated and presented in trables XII, XIII, XIV, and XV. overall efflelencles based on total reflux operation are in favorable agreement with the correlation proposed by 0 'Connell (Figure 8). The average devlation from the correlat ion $180.5 \%$ abaolute, or an error of $3 \%$. The maximum deviation was $6 \%$ absolut $\theta$, or an error of $19 \%$, obtalned from data for acetaldehyde-water fractionations. Th1s maximum deviation ocourred und or conditione whereby gmall errors in analysos or caloulations are exaggerated in the results. This effect onters through the extreme charact er of the equilibrium existing between ilquid and vapor (rolative volatility is 10 to 90). Consigtent doviations of from 8 to 10 \% were ebtalned uelng carbon tetrachloride-benzene. The relative velat1lity for carbon tetrachloride-benzene, 1.10 to 1.25 , Ind 1cates that the oquilibrium ourve is vory elose to the $x$ oqual $y$ line in the Hecabe-Thlele diagram, decreasing the accuracy of theoretion plate calculations.

The positive nature of the deviation was expected - Ince the officiency increases with increasing reflux ratio as point ed out for methanol-wat er fractionations (Figure 13). overall column officiencles obtained during cont Inuous operat Ions (P1gure 9) show excellent agreement 
Table XII Deviation of Results for Total Reflux Operations

Syst an

Ethanol-Water

Thanol-int or

Bensene-Teluene

Carbon tetrachloride-Benzene
Abeolute Deviation

7 Eefloienoy

0

1

2

6

7

8

6

2

2

4

$-7$

$-2$

$-5$

$-6$

$-6$

$-8$
Relative Deriation $x$

0

2

5

14

16

18

13

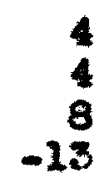

$-3$

$-8$

$-10$

$-10$

$-13$

Acetald enyde-nat er $\frac{1}{6}$

3

19

AVRRaE 0.5 


\section{Table XIII: Deviation of Colum Beflelencies for Continuous Operation}

Syat on

Ethanol -Nat er

Mothanol-Wat or

Ac etald ehyde-Wat er
Absolute Deviation

$\%$ Effletency
Relative Deviation $\%$
Benzene-Tel uene

Carbon tetrachloride-Benzene

$-1$

6

6

$-3$

$-3$

6

$-11$

$-10$

$-6$

$-2$

2

5

7

25 
Table XIV: Deviation of Rectifler Erflolenciea for Cont Inuous Operation

system

Athanol-Dater

Methanol-Dater
Abeolute Deviation

* Eeflaiency

7

0

2

3

7

7
Relative Deviation $\%$

16

0
4
7
15
15

$-18$

$-14$

$-5$

3

5

5

11

6

4

Table XV: Deviation of Stripper Erflelenclos for Continuous Operation

syat en

Mothanol-Wat or

Carbon totrachloride-Benzeno
Abselute Deviation

* Erficiency

17

18

19

19
Relative Deviation $\%$

44

44

49

49

$\begin{array}{rr}5 & 8 \\ 0 & 0 \\ 0 & 0 \\ -13 & -21 \\ -15 & -24 \\ -16 & -25\end{array}$

AVRAG 3

12 


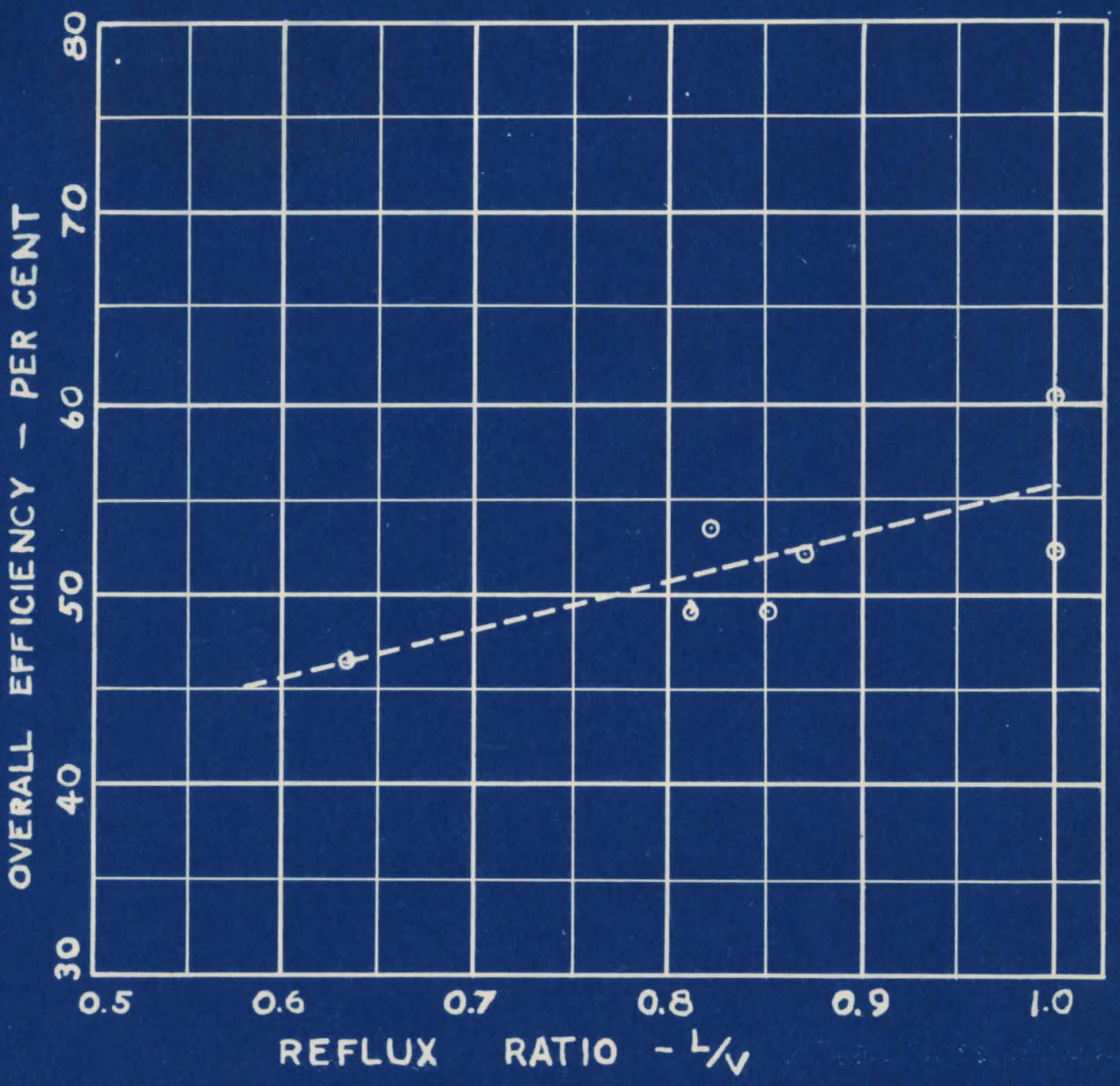

FIG. 13 - EFFECT OF REFLUX RATIO ON OVERALL EFFICIENCY OF RECTIFYING SECTION SYSTEM : METHANOL - WATER 
with the proposed correlation. The average deviation was $1 e 8 s$ than $1 \%$ absolute, or an error of $2 \%$. The maximum deriation was $7 \%$ absolute, or an orror of $25 \%$, obtalned during acetaldohyde-water fractionat ions. Again, the analyses and calculation for this system were the least consistent. Bxcluding the deviation for acetaldehydewater, the maximum deviation indleated an error of $18 \%$. Deviations up to 15 were not considered exceasive aince the operatione included various reflux ratios, and the effect of varying reflux ratio on plate officienoy has been present ed (Figure 13).

Result obtalned for orarall rectifier efflelencies (Flgure 10) shoned very favorable agreement with the proposed correlation. The absolute average deviation for this case was $2 \%$, or an orror of $4 \%$, while the aximum absolute deviation of $11 \%$, or $18 \%$ error, occurred during rectirication or carbon tetrachloridebenzene. The relative volat1lity during the operation leading to the 28 deviation was 1.13 . If the number of theoretical plates were recaleulat od on the basis of a relative volatility of 1.20 (3 \% decrease), the deviation would then be 4 . In vien of this, the deviations for carbon tetrachlorido-benzene seen umimportant. Stripper operations lod to efficieneios which deviated fron the correlation for central values of the 
viscosity-volatility product, but were in fair agreement for low valuea of the viscosity-velatility product. (Se Figure 11.) In the low range, the abolute deviation was $6 \%$, or an orror of $10 \%$, while in the contral range of viscosity-velatility produet the average absolute deviation was $18 \%$, or an orror of $46 \%$. This high deviation was obtained during mothanol-water fract lonation where the analytical procedure and the celculationg were most expl101t.

The avorage deviation of the reault by gystems (F1gure 12) were comput ed and are present ed in Table XVI. These results show excellent agreenent with the proposed correlation with the exception of otripper operations at viscoafty-volat1lity product great or than 1.0 . 
Table XVI: Deviation of the Arerage Result from the Proposed Correlation

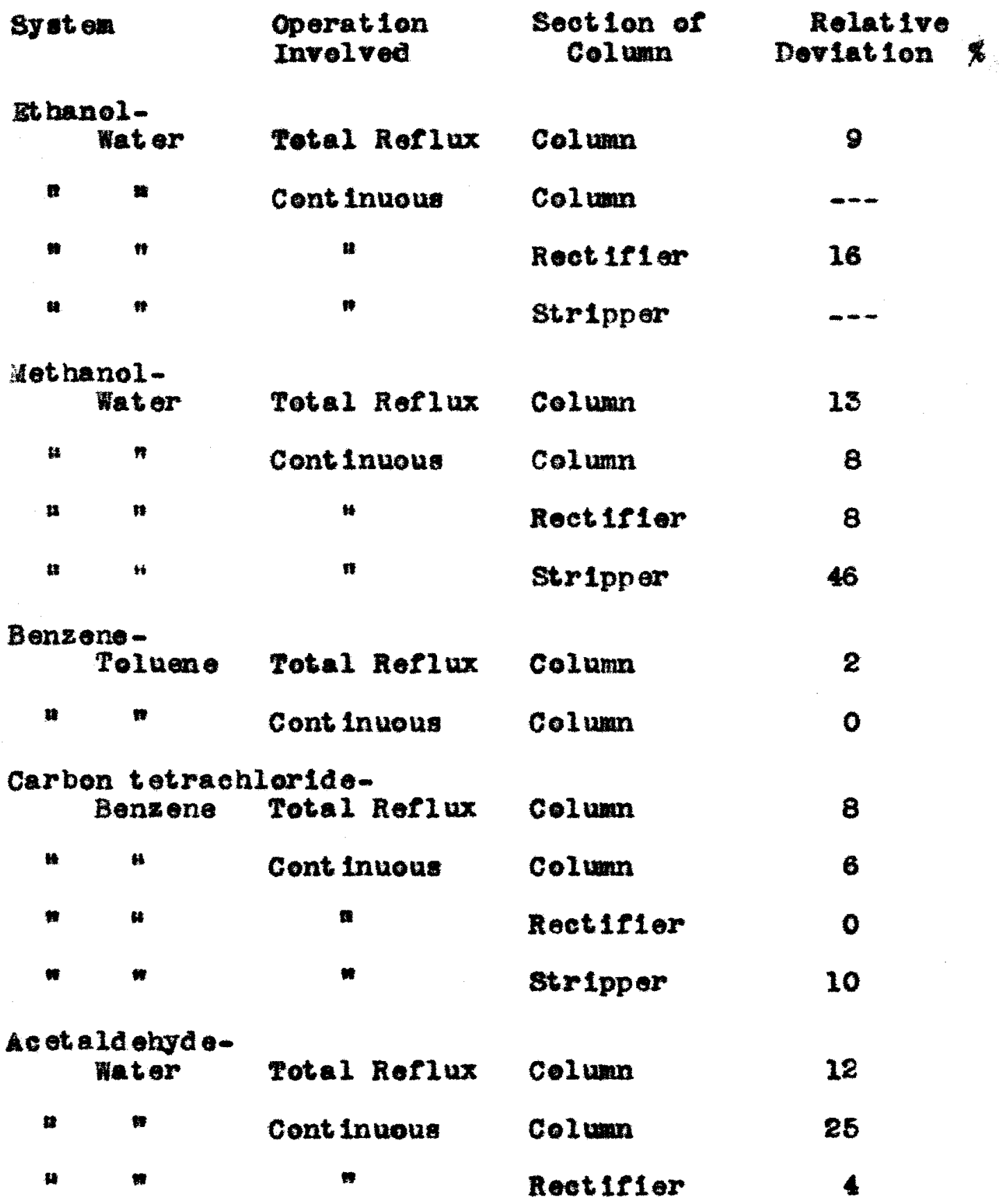


SUMARY AND COMCLUSIOUS 
overall affiolonclos for fractionations involving five different binary syat ems have been presented. The systems inoluded alcohol-water mixt ures, aromat 1c hydrocarbon-chlor Inat ed al1phat 1c hydrocarbon, two aromat io hydrocarbons, and aldehyde-water. Rectifier, strippor, and oolumn overall efficiencies during total reflux and continuous operation were correlated on the basis of tho viscesity-volat 121ty product, calculat od at the average temperature and composition in the respective portion of the celumn involved.

The correlation, although semi-empirical, may be used to prediet overall officlencles in commerclal Iract lonat ors under cortain limitations. For viscesityvolat1lity products betweon the values 0.1 and 10 , overall column and rectifler ection offiolencles may be predicted within the limits of mechanical design variables. Stripper officiencies for materials ylolding viscosity-volatility product 8 between 0.1 and 1.0 may be quite ecourately predicted, but predictions in the hlgher ranges of viscosity-volatility product should be used with discrotion. For uso of the correletion under circumstanses not apecified in this work, reference is made to an article by $0^{\prime}$ Connell (14).

The correlation is in substantial agreement with the correlation of $0^{\prime}$ Connell, and the types of systems heve 
been expanded. Although the entire investigation involved the use of binary aystems, the expansion to inolude mult icomponont fractionations seens possible in viow of the agreement between this correlation and the correlation of $0^{\prime C o n n e l l ~ w h i c h ~ i n e l u d e d ~ m u l t ~ i c o m p e n e n t ~ s e p a r a t i o n s . ~}$ 
(1) BRown, G.0., Irang. An. Inst, Chom, Bngra., 32, 321 (1936)

(2) BROWH, Q.G. and MARTI, B.Z., Trans. Am. Inat. Chem. Engrs., 35, 679 (1939)

(3) SHERmOOD, T.K. and JACKSON, R.M., mrans. An. Inst. Chem, Engrs,. 37, 959 (1941)

(4) SORBL, B., "Distillation ot Reotifleation", Par1s, Carrio and laud (1899)

(5) PEAVY, C.C. and BAKER, E.M., Ind. and Big. Chem., 29, 1056 (1937)

(6) BROFK, 0.0. and soudzRs, $4 .$, Ind. and Big. Chem., 28, 98 (1934)

(7) BROnS, Q.0. and LOCKHART, F., Trans. Am. Inst. Chem. Fingrs., 39, 63 (2943)

(8) CAREY, J., GRISWOLD, J., LBIIS, W. and MoADAMS, W., Trans. Am. Inst. Chem. Bagrs., 30, 504 (2933-34)

(9) KIRKBRIDE, C.Q.. Petroleum Refiner, 23, 321 (1944)

(10) GOOD, A.J., HUTCHIMSON, 1. H. and ROUSSEAU, W.C., Ind. and Ing. Chem., 34, 1445 (1942)

(11) WALTER, J.F. and SHERTOOD, T.K. Ind. and Bng. Chem., 33, 493 (1941)

(12) BEYAS, D.B. and BYMAN, L., Un1v, of Illinols Bng. Exp. Sta. Bull. Ho, 37, 50 (1941)

(13) DRICKAMER, H.G, and BRADPORD, J.R., Trans, An. Inst. Chem. Bngrs., 39, 319 (1943)

(14) $0^{\prime}$ Com Bs.L, H. B., Trans. Am. Inst. Chan, Bngrs., 42, 741 (1946)

(15) GERSTER, J.A., KOFFOLT, J.H, and WITHROW, J.R., Trans. Am. Inst. Chem. Ingrs., 39, 37 (1943) 


\section{LITERATURE CITED (Cont.)}

(16) CHILTON, T.H. and COLBUR, A.P., Ind, and Eng. Chem., 26, 1183 (1934)

(17) Von tarm, Th., Trans, A. S. M. E., 61, 705 (1939)

(18) HATELON, S. and ZUCKBRMAN, J.L., Ind, and Bg. Chem. (Ana 1. .), 17, 739 (1946) 
APPEDT 


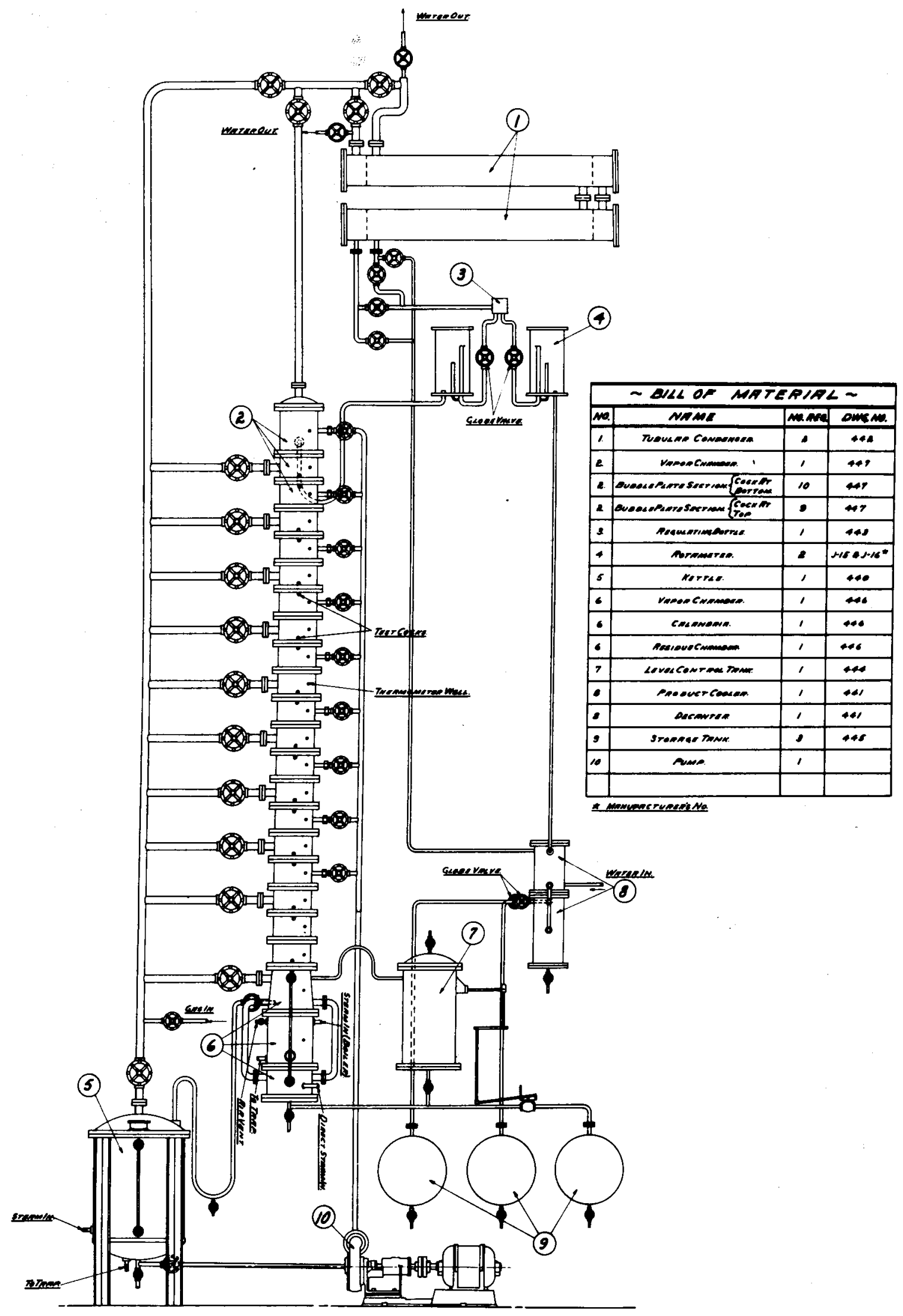




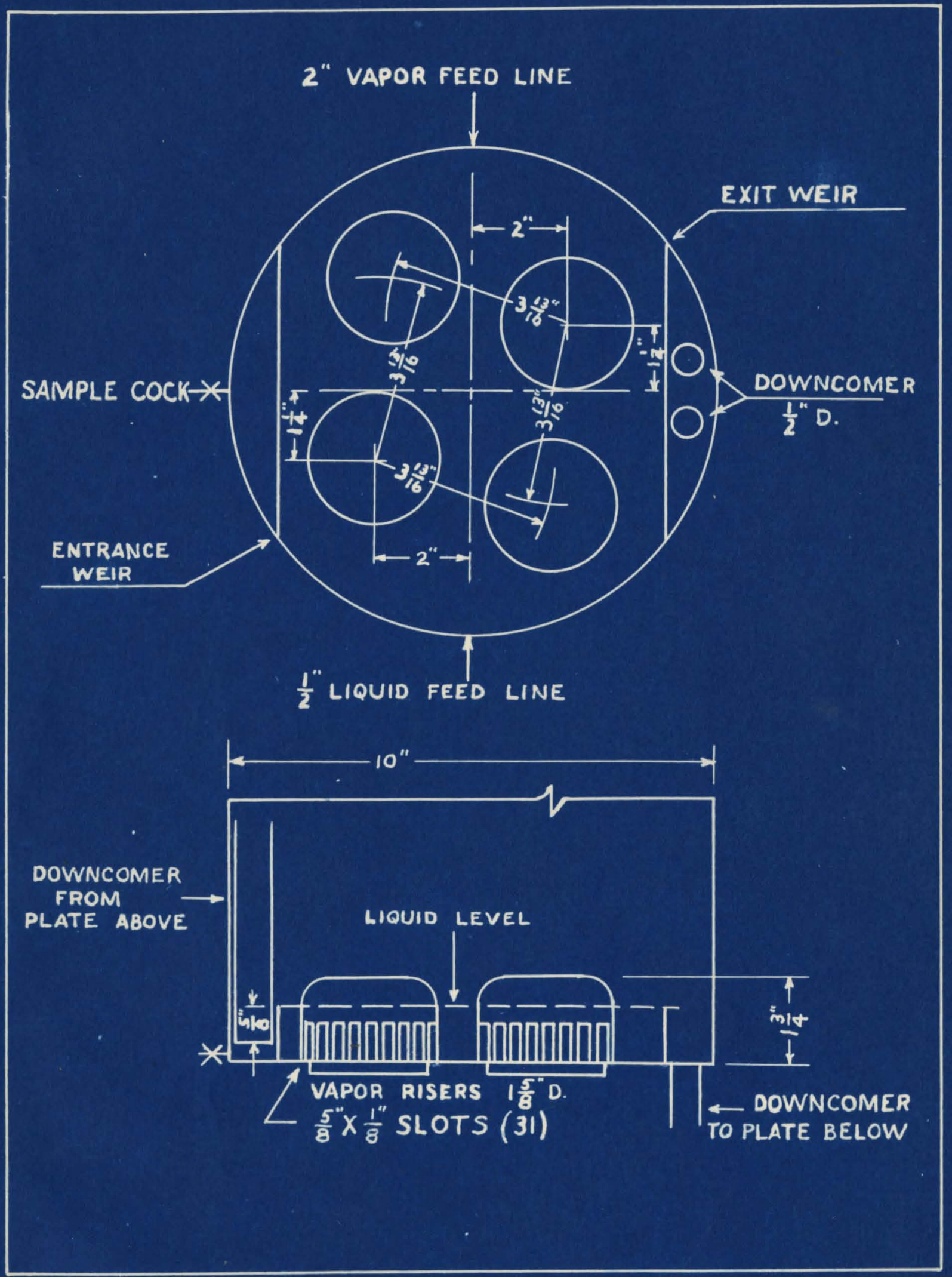

FIG.15-DETAILS OF PLATE CONSTRUCTION 


\section{SAMPLE CALCULAT IONS}

These calculations are for fun No. 11 ,

methanol-wat er.

Yapor Veloeity

$$
\text { Vep. Vel. }=\frac{\text { wd }}{3600(3)(273) \pi D^{2}}
$$

where, $\quad$ Id $=$ Pounds vapor/hour

$$
\begin{aligned}
& M=\text { Loleoular welght of product } \\
& t_{1}=\text { Temperature, platel (degrees } K_{.} \text {) } \\
& D=\text { Colum diameter, feet }
\end{aligned}
$$

Vap. Vel. $=\frac{(39+66)(359)(339)(144)(4)}{36007.948 \times 32+.052 \times 18)(273)(\pi)(10)^{2}}$

Vep. Vel. $=0.76 \mathrm{ft} . / \mathrm{sec}$.

Rerlux Ratio

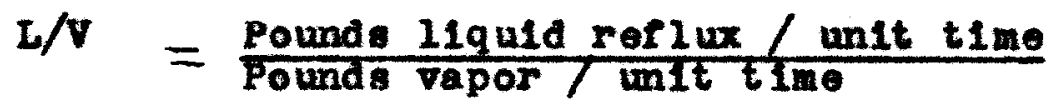

$$
\begin{aligned}
& \boldsymbol{w}=\frac{66}{66+39} \\
& \boldsymbol{L} / \boldsymbol{V}=0.63
\end{aligned}
$$

Material Balance

Methanol input in feed $=w f(w t . ;$ methanol $)$

$$
\begin{aligned}
& \text { * * * } "=115(0.294) \\
& \text { " " * }=33.8 \text { pound / hour }
\end{aligned}
$$

Methanol in product $=\pi p$ (wt. \% nethanol)

$$
\begin{array}{rl}
* & =39(0.972) \\
* & * \quad=37.8 \text { peund } / \text { hour }
\end{array}
$$

nethanol in waste $=$ Negligible 
Mat erial Balance (Cont.)

Bazance $=\frac{100 \text { (output) }}{\text { (1nput) }}$

Balance $=\frac{100(37.8)}{33.8}$

Balance $=112 \%$

(waterial balances within 80 to $120 \%$ wore considered within the limite of the exporimental data.)

sipoe or q Line $\left(\frac{q}{q-1}\right)$

$q=\frac{\text { lat ent heat of reed at foed temporat ure }}{\text { latent hoet of foed at bolling point }}$

$q=1+\frac{\text { sensible heat (tb to } t f)}{\text { Iatont host tot } t b}$

$q=1+\frac{(85-60)(.81 \times 18+.19 \times 22.5)}{.81(9720)+.19(8410)}$

$q=1.05$

slope of q line $=21$

Theoretical Plates

The number of theoretical plates was calculated by the mothod of mocabo-rhlele. The oquilibrium data were plotted In Pigure 16, and the rectifler operating line drawn from $X p$ at alope of $\mathrm{L} / \mathrm{v}$. From the $\mathrm{X}$ equal $\mathrm{Y}$ line at $\mathrm{XF}$, the $q$ line was dram with a slope of 21 to intersect the rectifier operating 1ine. From this intersection to XW, the stripper operating line was dwarn. By a stepwise calculation from $X 19$ to $X 1$, the number of theoretical plates was found to be 9.15 . 


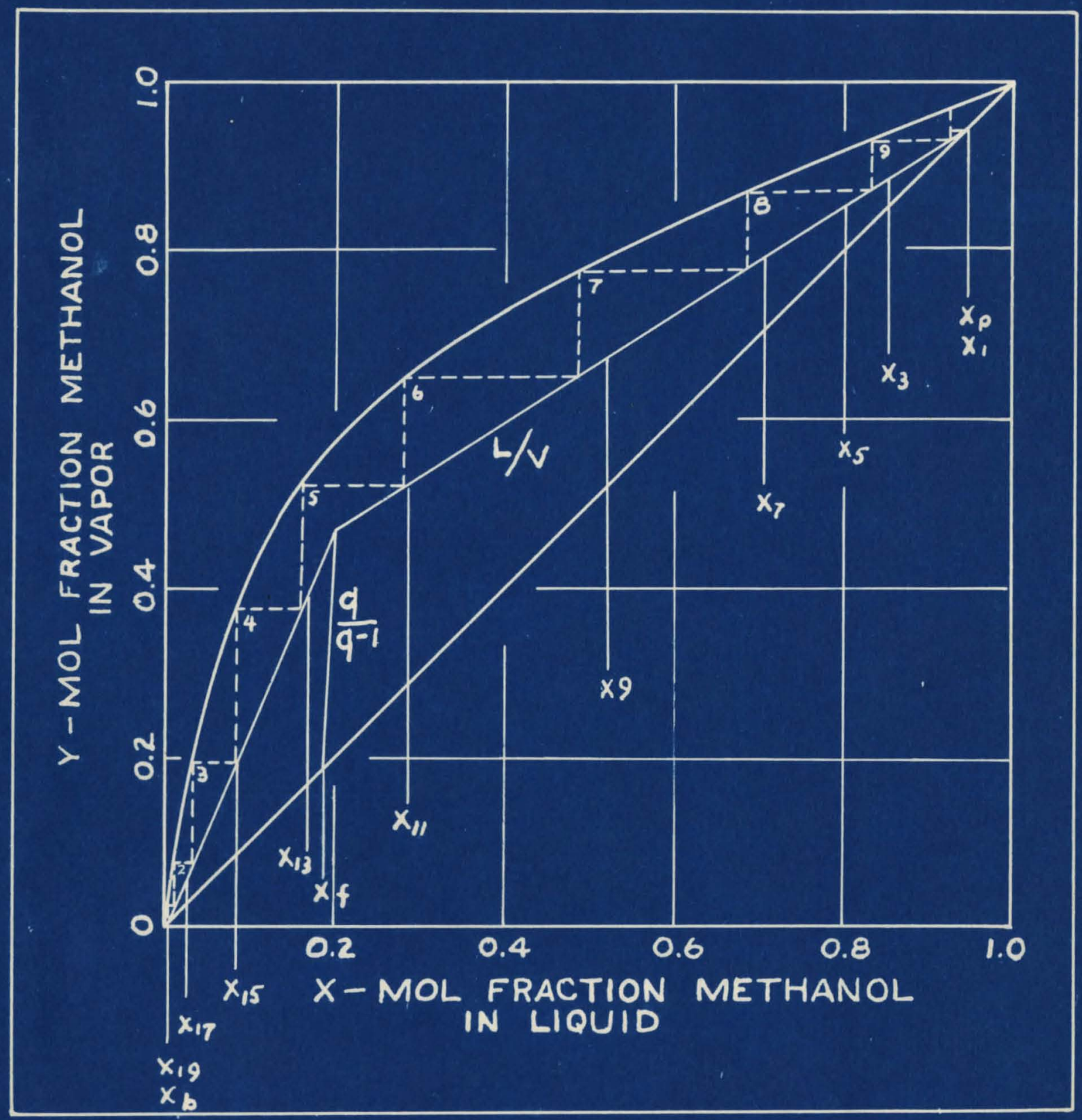

FIG.16-SAMPLE CALCULATION OF THEORETICAL PLATES. (METHANOL-WATER FRACTIONATION) 
overal1 affolenoy

$$
\begin{aligned}
& \text { Effloleney }=\frac{(200) \text { theoretieal plates required }}{\text { actugl plates used }} \\
& \text { Bffloteney }=\frac{100(9.15)}{18} \\
& \text { EFfloleney }=50.9 \% \text { (Ovorall column offleiency) } \\
& \text { Stripper and rectifior officlenelos wore calculated }
\end{aligned}
$$

In the same manner, using different end values for $x$.

Relative Volatility $(\alpha)$

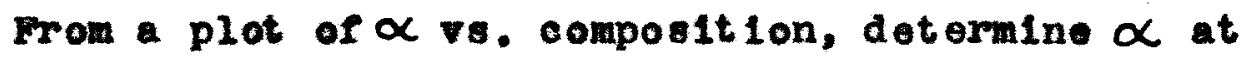
the average composition in the section. $\alpha=3.8$. Psuedo Molal Viscosity $(\mu)$

$$
\begin{aligned}
& \mu=x_{A} \mu_{A}+x_{B} \mu_{B} \\
& \mu=.44(.33)+.56(.36) \\
& \mu=0.35
\end{aligned}
$$

viscosity-Volatility Product $(\mu \alpha)$

$$
\begin{aligned}
& \mu \alpha=0.35(3.8) \\
& \mu \alpha=1.33
\end{aligned}
$$


IOA EMCLATUR

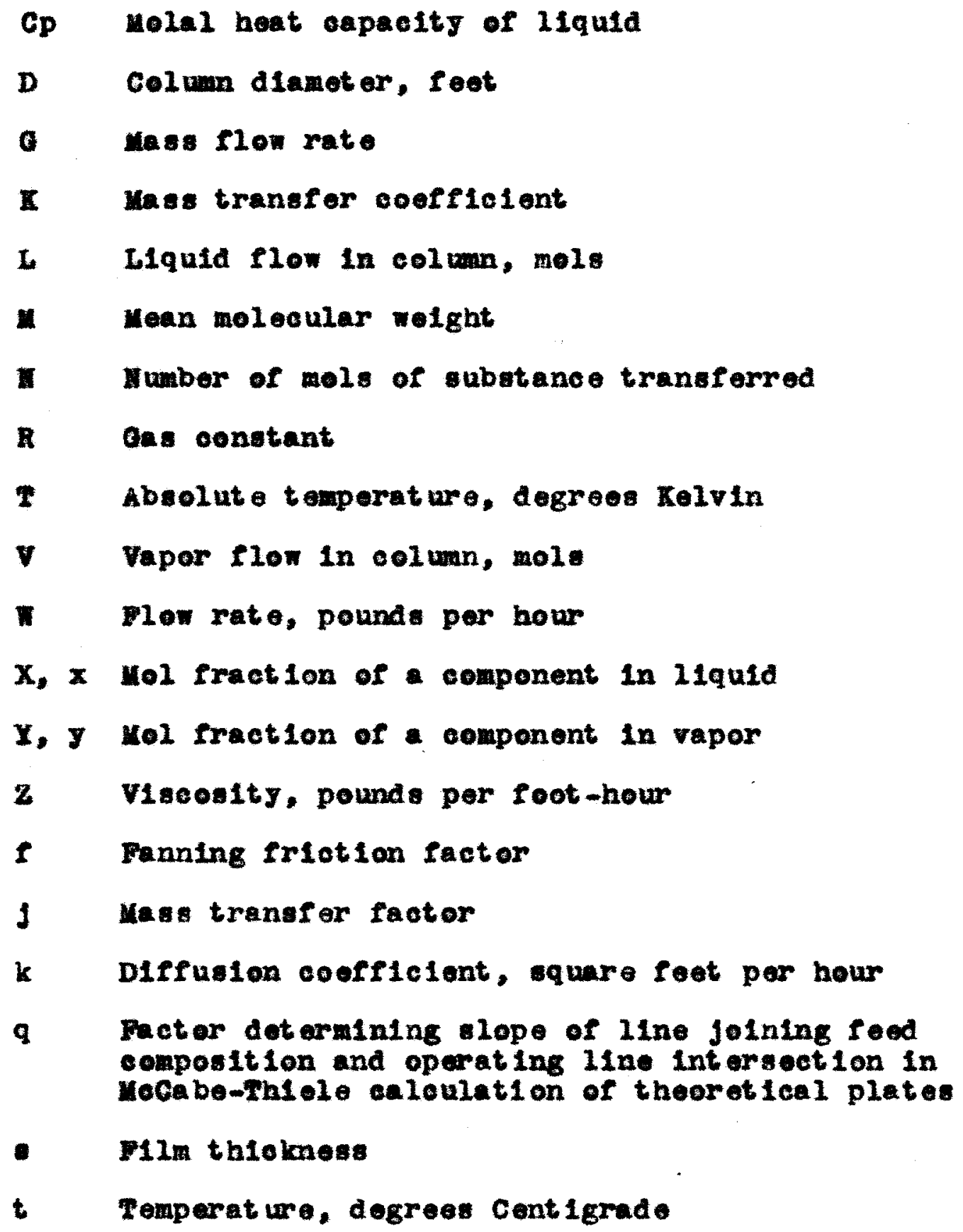
composition and operat ing line intersection in recabe-Thiele caloulation of theoreticel plates

- P1In thiolmess

t Temperat ure, degrees Cent igrade 


\section{HOL ERCTATURE (Cont.)}

$\alpha$ Relative volatility

$\mu$ Pauedo molal viscosity

$\lambda$ Lat ent hoat of raporization

$\rho$ Density, pounds por cuble foot

Subsoripts
A More volatile component
B Lees rolat1le component
b Bolling point
a Distillate
1 Foed
p Product
- Bottoms, wasto
1, 2, 3, Plate number from top (top plate No. 1) 


\section{ACKN ONL BDOM BAT}

This research was made possible through a fellowiplp grant from

the University of Loulaville Institute of Industrial Researoh as a portion of contracted research with

the Sthyl cerperation 


\section{VITA}

Hri Kenneth st1gger, son of clifford $T$. and Elnora (Knauer) St 1gger, was born in Loulev1lle, Kentucky, June 12, 1920. After a omploting grammar school in Loulsville, he entered duPont Hanual Training High School and Craduated Valedictorian in 1938. Bntering the speed Selentific Sehool of the Dniveraity of Louleville in 1938, he pureued a course in Chemical Angineoring, recelving the Degree B. Ch. B. In June, 1942. Ho was presented the A. I. Ch. B. Student chapter eward at the close of the sophomore year, and won three awards in recognition of his scholarship in 1942 .

Aft or two years industrial experionce with monsanto Chemical Co. (St. Louls) and two years service in the U. S. H. R., he re-enterod the spoed selentifle sehool In 1946, recelving the Degree M. Ch. B. In March, 1947. 